Florida International University

FIU Digital Commons

\title{
What's Past is Prologue: Transforming Trauma, Rewriting Identity in Gloria Anzaldua's "Borderlands/La Frontera" and "Light in the Dark/Luz en lo Oscuro"
}

Richard Edward Riley

Florida International University, rrile010@fiu.edu

Follow this and additional works at: https://digitalcommons.fiu.edu/etd

Part of the Chicana/o Studies Commons, Comparative Literature Commons, Continental Philosophy Commons, Latina/o Studies Commons, Literature in English, North America, Ethnic and Cultural Minority Commons, and the Modern Literature Commons

\section{Recommended Citation}

Riley, Richard Edward, "What's Past is Prologue: Transforming Trauma, Rewriting Identity in Gloria Anzaldua's "Borderlands/La Frontera" and "Light in the Dark/Luz en lo Oscuro"'' (2020). FIU Electronic Theses and Dissertations. 4399.

https://digitalcommons.fiu.edu/etd/4399

This work is brought to you for free and open access by the University Graduate School at FIU Digital Commons. It has been accepted for inclusion in FIU Electronic Theses and Dissertations by an authorized administrator of FIU Digital Commons. For more information, please contact dcc@fiu.edu. 


\title{
FLORIDA INTERNATIONAL UNIVERSITY
}

Miami, Florida

\section{WHAT'S PAST IS PROLOGUE: TRANSFORMING TRAUMA, REWRITING \\ IDENTITY IN GLORIA ANZALDUA'S “BORDERLANDS/LA FRONTERA” AND \\ "LIGHT IN THE DARK/LUZ EN LO OSCURO"}

\author{
A thesis submitted in partial fulfillment of \\ the requirements for the degree of \\ MASTER OF ARTS \\ in \\ ENGLISH \\ by
}

Richard E. Riley 
To: Dean Michael R. Heithaus

College of Arts, Sciences and Education

This thesis, written by Richard E. Riley, and entitled What's Past is Prologue: Transforming Trauma, Rewriting Identity in Gloria Anzaldua's "Borderlands/La Frontera" and "Light in the Dark/Luz en lo Oscuro", having been approved in respect to style and intellectual content, is referred to you for judgment.

We have read this thesis and recommend that it be approved.

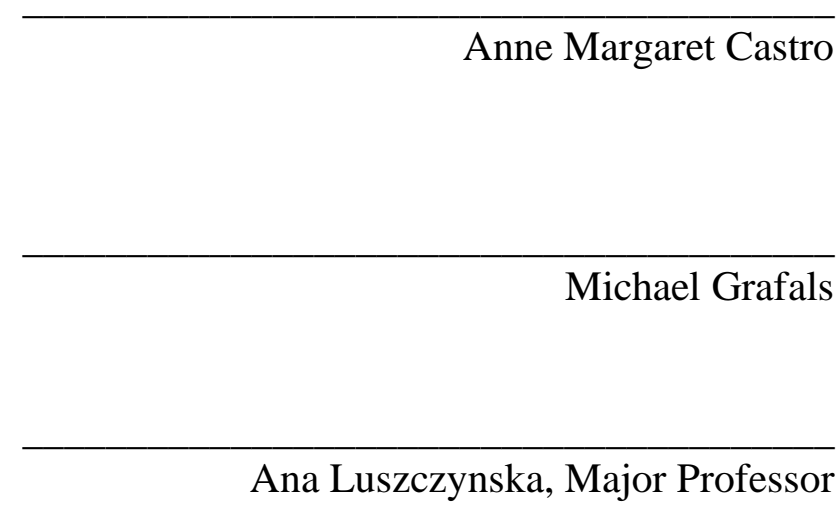

Date of Defense: March 24, 2020

The thesis of Richard E. Riley is approved.

Dean Michael R. Heithaus College of Arts, Sciences and Education

Andrés G. Gil

Vice President for Research and Economic Development and Dean of the University Graduate School

Florida International University, 2020 


\author{
ABSTRACT OF THE THESIS \\ WHAT'S PAST IS PROLOGUE: TRANSFORMING TRAUMA, REWRITING \\ IDENTITY IN GLORIA ANZALDUA'S “BORDERLANDS/LA FRONTERA” AND \\ “LIGHT IN THE DARK/LUZ EN LO OSCURO” \\ by
}

Richard E. Riley

Florida International University, 2020

Miami, Florida

Professor Ana Luszczynska, Major Professor

Gloria Anzaldua's "Borderlands/La Frontera" and "Light in the Dark/Luz en lo Oscuro" are widely acknowldged as groundbreaking texts across Latinx literary canons, invoking selfhood, spirituality, activism, and politics as a queer woman of color writer.

Her language around self-dispersion is still undertheorized in what it owes to traumatic experiences discoverable in the self, body, world, and culture Anzaldua hails from. The extent of colonizing and kyriarchal damage in her work has been recognized; but the exact character of how these breakages and corresponding imperatives to regenerate oneself resemble a traumatic shock remains to be written about.

This thesis sketches frameworks appropriate to the task, employing phenomenology, deconstruction, psychoanalysis, and theories of trauma and testimony alongside Anzaldua. Connections between each intellectual movement are uncovered in juxtaposition with Anzaldua's texts, and novel readings arise with respect to Anzaldua's worldview and the internal logic of death, pain, and rebirth unique to her experiences. 


\section{TABLE OF CONTENTS}

\section{CHAPTER}

PAGE

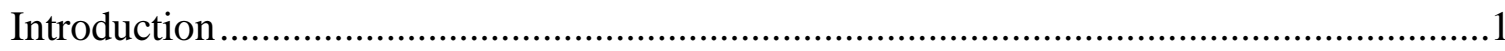

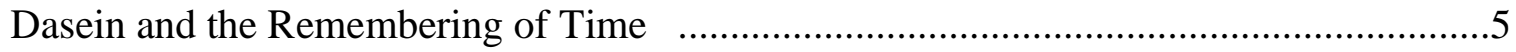

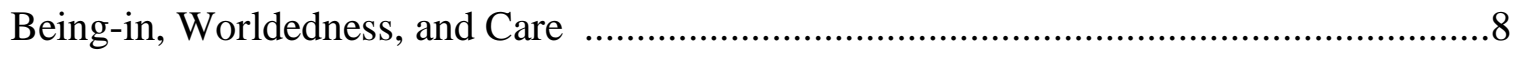

Ekstasis, Historicity, and Implications for Further Criticism ....................................12

Oneself as Temporal -- Differance and the Augenblick .............................................14

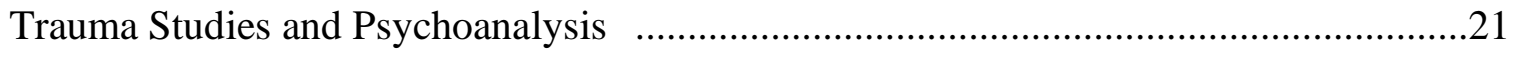

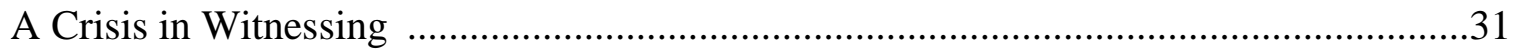

The Phenomenology of Trauma - Anzaldua (Un)Bound ..........................................41

A Life claimed in Wounds: the Pains of a Queer Chicana Poet .....................................45

The Shadow is our Tyrant, and our Savior: A Reformatting of Ourselves.......................50

Beyond Good and Evil: Refashioning Ourselves as Healing ......................................55

Conclusion: Nepantlera, Once More ..................................................................62

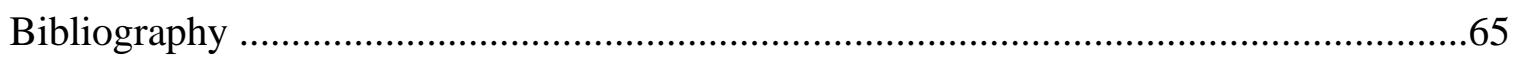




\section{Introduction}

The writings of Chicana feminist thinker Gloria Anzaldua have over the past thirty years gradually been welcomed not only into the canon of Latinx literature and philosophy, but into the wider world of cultural and language studies. Anzaldua's thought has influenced movements in indigenous and third-world feminisms, and contributed new insights to our knowledge of writing \& rhetoric, religious studies, and queer theory. But Anzaldua's work, in my estimation, is much more than an object for academic study: it is a self-portrait, a log of the internecine battle one human-being has undergone in the fight for their own self-worth, wrenched from the maw of a society bent on their destruction. It is a painstaking repository of the wounds she has felt branded into her body, in the literal sense of flesh and in the larger metaphorical sense of culture, history, and world, and the process of a recovery wrung out from the older selves preceding every possible future one. And every step of this fight is mapped out, like a manual, with its readers in mind, a relation of discourses as well as events from the author's personal life, with one goal in mind: a toolkit for a collective ritualizing of her own process. Anzaldua's writings indicate a deep connection to one's heritage and upbringing, a past stretching from childhood into adult life, careful and vigilant for the atoms of spirit and asteroids of traumatic experience around every corner. It is this connection, this faculty enabling a reading of the world entirely given to her own survival, which produces a testimony and artistry seen only in the likes of other greats from the Black and Latinx traditions; Anzaldua makes herself possible, and she achieves this by rewriting the book on survival, on pain and wounds and creativity, and the limits of the imagination. 
Arriving to her writing with the right context and mindset will make the aforementioned threads more apparent. In the spirit of facilitating this understanding, this thesis will undertake an explication and recontextualization of multiple academic discourses: phenomenology through Martin Heidegger, deconstruction through Jacques Derrida, psychoanalytic theories of trauma through Sigmund Freud and Cathy Caruth, and premises regarding the acts of testimony and bearing witness borrowed from Shoshana Felman and Dori Laub. The result will be a framework better equipped to read Anzaldua for the innovations distinct to her work, in addition to ensuring a firm theoretical grounding in several discourses already established for their credible interventions and epistemologies.

If the lenses are manifold, the object is singular: traumatic experience, and its effect and relation to the self. While apparently straightforward enough a matter, the reality hardly is. As Lucy Bond \& Stef Craps point out in their survey The New Critical Idiom: Trauma, the traumatic experience "is slippery: blurring the boundaries between mind and body, memory and forgetting, speech and silence.” (Bond \& Craps, 5) It is abundantly clear the type of delicacy required by an inquiry into traumatic memory and interpretation, and the consequent nuance and intricacy of a phenomenon that continues to elude the grasp of most advanced theoretical frameworks.

It is this aspect of traumatic experience that phenomenology and deconstruction can make good on their analytic promise about. A close-up on the lived experiences linked to traumatic recollection and repetition discloses certain kinks and quirks unseen by a generalized discursive or psychoanalytic treatment of the phenomenon from the outside: the absolute alterity of repressed memories to my awareness; the processes of 
meaning-disruption and creation a survivor experiences; a more ethical type of listening that precludes a myriad of medicalizing and pathologizing practices that make up the byproducts of certain scientific discourses; and the direct and firsthand relating of my experience qua testimony to others. Psychoanalysis, for its part, adds its developed corpus of concepts from which much discourse surrounding trauma gets its start from, with Caruth and Felman putting a new twist on old news and thereby injecting fresh blood into the conversation.

Phenomenology does have its limits — in particular with its subject-centered and Cartesian proclivity for describing consciousness — and yes, poststructuralism and other cognate theoretical frameworks have achieved much in questioning the dominance of subject-centered philosophies through western intellectual history. The quandary relevant to these books, however, has everything to do with intersubjective hermeneutics, which is to say that the subject being understood or misunderstood crisscrosses matters of representation and meaning with real material stakes; the tendencies of the latest trends in studies of collective culture and discourse run headlong into a direct confrontation with particular, individual experience. The care and concentration applied to lived experience in phenomenological reading combined with the anti-essentializing and anti-structural aspects of deconstruction make for a mobile analytic, one that can be pinned up for long enough to center the subject's lived experience without sacrificing resiliency and openness to historical contingency. It is an acknowledgement of an awe at the brute presence of others within our meaningful milieu, and their unrepresentable being at the frontiers of our own subjectivity. 
The question of bearing witness and the presence of others is thus resolutely entangled in lived experience and language, in text and body, a sort of inscribed corporeality. The balancing of "the internal and the external, the private and the public, the individual and the collective" (Bond \& Craps, 5) that Bond \& Craps point out as the threshold space of trauma not only straddles the descriptions of self, temporality, discourse, and lived-world characteristic of phenomenology, and the dream-work, repression, ego-formation, and repetition compulsions posited by psychoanalysis. These two discourses also intersect with a third, one more incisive than phenomenology while being just as, if not more, sui generis than psychoanalysis. Gloria Anzaldua's works Borderlands/La Frontera and Light in the Dark/Luz en lo Oscuro themselves open up into the third space she theorizes, incorporating properties from both domains of thought and staking out their own territory within a theory or writing the self into the body, regenerating one's worldedness in the course of healing deep psychic wounds caused by those same factical circumstances. In putting into practice a regimen of deep psychic introspection and conflict-resolution, Anzaldua's accomplishment consists in a construction reflected from personal materials; through writing, she seamlessly incorporates and accomodates theoretical conclusions of others with her own living existence theory, a body-narrative befitting the term "auto-theory". In taking on the task of theorizing, writing, on oneself (i.e. about oneself and on oneself, one's body) Anzaldua integrates concepts in both traditions while surpassing many of their limits. She supplies valuable alternatives to a theorizing of trauma, including the role writing has on bodily motions, processes, and contexts, and opens the way for Post-Cartesian ontology. Most important of all perhaps is her transcendence of divisions between theory and praxis 
by way of her autohistoria, leaving the boundaries of abstract and generalized theoretical writing behind for a more personalized, and therefore energized and impactful, mode. In order to better comprehend Anzaldua's groundbreaking step forward, a walk-through of certain theoretical frameworks and their findings will precede the reading of the two texts themselves. We will overview the work of Martin Heidegger, Jacques Derrida, Sigmund Freud, Cathy Caruth, Shoshana Felman, and Dori Laub before advancing to Borderlands/La Frontera and Light in the Dark/Luz en lo Oscuro. Starting off with Heidegger, an analysis of human subjectivity as irrevocably concerned with practical connections to one's world and to others, and itself constituted in time, will underlay our elaborations into the nature of trauma, its wounds to the self, and what recovery — or in her case, reconstruction - may look like.

\section{Dasein and the Remembering of Time1}

What does human-being or human subjectivity resemble more: an immortal kernel descended from a supraphysical plane, pure and inalterable during its stay in the material world; or a shifting, indeterminate, nonspecific material? Is it whole and unified, an entity surviving the flesh and ascending into the firmament upon death? Or does our finitude hang off our bones, defining our every act and project? German philosopher Martin Heidegger's Being and Time (1927) takes up this question in both its most radical and its most primordial form: what is Being? And what does it mean to be?

1 Heidegger's magnum opus, Being and Time eludes all facile articulations. It is, for the purposes of a chapter of this length, an unfathomable complex of analysis. Given the practical limits of a thesis of this nature, a sophisticated and exhaustive explanation of Heidegger's existential analytic will prove just as elusive, and by design outside of our scope. Therefore, the author appeals to the reader's understanding if some holes in explanation are left unfilled. Certain presuppositions are inevitable in all written work, and this critical read be no different. 
But first: how can such a fundamental question -- what Heidegger, in fact, refers to as the fundamental ontological question — be both radical and primordial? The answer is simple: it is radical for being so primordial, so closely interlaced with our direct experience and the questioning itself. This direct and primordial encounter with our existential subjectivity is not something we're accustomed to, nor in fact ever fully prepared for, given what Heidegger refers to as our "falling-prey-to", the condition we always already discover ourselves in as subjects thrown into a world not of our own making, one in which all of our agreements are assumed, our conformity is uncontradicted, and our complacency is obscured even to ourselves. To Heidegger, this falling-prey is a fact of human subjectivity, a quality he refers to as an "existential" common to all subjective human experience.

The reason for this fundamental questioning is also simple in its explanation, while radical in its assumptions and implications. The reason is this: Heidegger wants to return to asking this fundamental question, one that has been erased from the history of metaphysics after a suite of what he considers unacknowledged and ignored missteps. But in the way of this question is a questioning of the questioner themselves - who is asking this question of Being? And what is their being? He decides that any ontological question - that is, one questioning what it means for any given thing to be - requires an understanding of ontology that can only be arrived at through the being that represents the kind of questioning towards the world that ontology represents, and this is only to be found in "Dasein"2. Heidegger will spend the remainder of Being and Time outlining the

2 In the German, transliterated as "being-there". One of Heidegger's most radical repositionings is against the Humanist articulation of human-being, one concerned with a strong and indomitable core essence of humanity seemingly outside of time in its eternity. Heidegger's position is more radically intriguing: the 
existential features of Dasein, his re-conception of human-being, and its fundamental structuring as temporality itself. While Heidegger has not entirely answered his own question by the end of the book, what he has done in the interim is produce a pathbreaking reconstruction of the essence of human-being by eradicating the metaphysics standing in his way.

What, however, do these metaphysics consist of? And what is it about human essence that Heidegger is fooling around with in the first place? Here the answer becomes complex, while remaining deceptively simple. Heidegger believes not just metaphysics, but institutional research of the empirical sort (what we call the modern sciences, both humanistic and physical) is constantly undergoing a revitalization of its core concepts. This is because their objects of study, whether mathematical formulas, plant species, or human societies, are always already re-examining the very subjects they first looked at to produce their organizing principles. This is happening unconsciously: Heiddegger just thinks that we must acknowledge these objects of study as themselves beings, as objects that are ontologically interesting when it comes to asking the question: what is a being? What is this particular being's being?3 And philosophical metaphysics since the Greeks, to be clear, has misnamed or outright misunderstood the object of study for a fundamental ontology. What it has misunderstood is "time" itself. Lines have been drawn in the sand between temporal and atemporal beings, what western metaphysical discourse

first defining feature of Dasein is the fact that "in its being this being is concerned about its very being." (11)

3 Being and Time, p. 9 
has concerned itself with in past millennia4, while overlooking the critical overlap between what it means to be as time for human-beings, or Dasein. What is most critical among his findings is the re-seating of temporality as the essence of human-being, thus dethroning essence itself as something timeless and ideal as a project for understanding human nature. Dasein must revive, by its own questioning, its awareness of its own being-as-time, as that is constituted as being-in, worldedness, care, ekstasis, and historicity.

\section{Being-in, Worldedness, and Care}

To adequately make sense of Heidegger's core existential framework -- Dasein's being as "care" -- we must begin with an analysis of what there is for us to take care $o f$. To this end, he will embark on an analysis of world and reality as to what their primordial existential significance is for concrete human existence, and in the process break down objectified notions of world that do not take into account human-beings direct encounter with other beings.

Following this thread, "worldedness" is a key term we cannot avoid. In pursuing the ontic-ontological distinction and his corresponding focus on the analysis of the ontological conditions of human-being, Heidegger wants to re-appraise our historic understanding of "world" and "reality" not as mere beings that exist, objectively and without our contribution, but as they reveal themselves in their Be-ing to Dasein, the

4 “"Time' has long served as the ontological - or rather ontic - criterion for naively distinguishing the different regions of beings. 'Temporal' beings (natural processes and historical events) are separated from 'atemporal' beings (spatial and numerical relationships). We are accustomed to distinguishing the 'timeless' meaning of propositions from the 'temporal' course of propositional statements." (18) 
existential processes whereby we make sense of the objects and people we exist through and as. By way of clarification, Heidegger specifies that "worldedness", to him, means not the "totality of beings which can be objectively present within the world" (Heidegger, 64) nor even the ontology of those same beings and the multiplicity thereof. Instead, Heidegger's suggestion is to conceive of "worldedness" as "that 'in which' a factical Dasein 'lives' as Dasein." (Heidegger, 65) It is, fundamentally and foremost, a "kind of being of Dasein, never a kind of being of something objectively present 'in' the world." (Heidegger, 65) What we uncover as "objectively present", those objects which we posit as existing prior to our subjective encounters with them, are actually not the most primordial means of being-in as Dasein that we exist in. Heidegger's response to this objectifying tendency is to remind us of the "handiness" of things as we respond and react to them in our being-in-the-world. In our "dealings" with the worlds of our being-in, we answer to other beings in our taking-care in a utilitarian sort of fashion, as things in their pragmatics disclose themselves in relation to our own being. For instance, we do not primordially evaluate a chair as a block of upholstered wood with four legs and in a mahogany finish, but as a useful "means" to our potential sitting on it or standing up away from it. And these orders of reference are never singular, but manifold, the referentiality of which Heidegger calls "circumspection". (68-9)5 This circumspection, as we will learn, becomes explicit only in the exposure to references among beings-at-hand that signs provide.

5 "Conspicuousness", "obtrusiveness", and "obstinancy" are three modes of the dysfunction of our everyday useful dealings with objects. These moments of discord with our useful objects disclose our exact factical involvement with innerworldly beings in Daseins peculiar form of subjectivity. 
Co-extensive with our practical dealings as beings-in-the-world and what we find useful or serviceable in our everyday existence are signs and indications, and the sphere of reference in which they operate. Indeed, "Signs are not things which stand in an indicating relationship to another thing" Heidegger asserts; "rather, they are useful things which explicitly bring a totality of useful things to circumspection so that the worldly character of what is at hand makes itself known at the same time." (78) The primacy of signs lies in their disclosure of reference relations among handy objects, and the circle of signification they are responsive and connected to.

The second of Heidegger's critical interventions constitutes the existential analytic of Dasein as "being-in", that is, a being fundamentally "taking-care-of" that which constitutes its worldedness. To dispel a misconception from go, Heidegger clarifies that the word "in" does not indicate an "objective" or spatial being to be found in or as a place, but a kind of being on a different order than what he calls mere "innerworldly beings"6. Dasein's being is in, and uniquely distinct from inanimate objects in the world around it, on account of its facticity and care-structure -- what amounts to its collected factical circumstances, where and when it finds itself existing in geography, culture, race, gender, etc, and the concern it has for what makes up its environment, meaningful surroundings, and fellow human-beings. In other words, "The being which is essentially constituted by being-in-the-world is itself always its "there."' (129) That is to say that the being whose essence is existence and existing - what for Heidegger means flowing and changing as time - what makes this being itself is where it

6 “...being-in not as an attribute of an objectively present subject effected or even just triggered by the objective presence of the 'world'; rather, being-in essentially as the kind of being of this being itself." (128) 
finds itself, its "there", the aforementioned factical circumstances it must always already be inhabiting and negotiating. No subject, no human-being, is exempt from the particularity of their historical experiences.

Heidegger notes that the makeup of being-in can be characterized as tantamount to the descriptions of two co-constitutive existential characteristics of Dasein: "attunement" and "understanding". These are equiprimordial, a term Heidegger uses to emphasize the non-particular and unsourceable character of each existential to Dasein's being. Attunement is nothing less than Dasein's manifestation of its facticity and thrownness, its sometimes acute, sometimes latent, and always pre-cognized state of response and inhabitation according to the world in which it resides. This response can be referred to as "moodiness", the sense in which our attunement takes the form of affective attachments to our surroundings that, in turn, disclose our relation as being-in in a particular manner or mode, and that display themselves pre-cognitively, beneath our everyday awareness. Mood, according to Heidegger, "has always already disclosed being-in-the-world as a whole and first makes possible directing oneself towards something." (emphasis original, 133). In other words, moods are our first line of contact with the world. Except that we are neither separate from our moods, nor are our moods separate from the bed they spring forth from, our worldedness, leaving us more holistically trussed to our facticity than a subject-object dichotomy can reasonably explain.

Understanding is the second of what Heidegger considers the two existentials comprising being-in. This is the fundamental ground of what it means to be as Dasein, as a being taking-care-of its world. Summarizing his earlier deductions, he states: "Being-in 
is "there" as that for the sake of which Dasein is. Existing being-in-the-world as such is disclosed in the for-the-sake-of-which, and we called this disclosedness understanding." (emphasis mine, 139) Significance and the for-the-sake-of-which, i.e. possibility, are the genesis of understanding itself, and these require explication. To be direct, significance is the attachment of our being to other beings via sense-giving and language; and the forthe-sake-of-which denotes a living and fluid project-ing, the manipulation of our being-in by dint of our projects and possibilities. This is all to say that what we are capable of understanding hinges on meanings not only dependent on the totality of our worldedness, but also the combined significance (i.e. import, weight) of our practical and concrete projects and possibilities. Only at the intersections of what we care about and what makes sense to us inside our cultural milieu can understanding be disclosed to us.

\section{Ekstasis, Historicity, and Implications for Further Criticism}

A final set of ideas bring to a close the circle of interpretation Heidegger has thus far brought us into. To complicate the analysis of Dasein as being-in-the-world that takescare-of, we must finally introduce time and historicity to the equation, an unspoken gap which has not been given its due up until Division II of Being and Time. The particulars of the structure of Dasein have prepared us to understand multiple features of humanbeing that usually get taken for granted: the fundamental essence of human existence, the significant beings which make up our circles of reference and our worldedness, and our understanding and attunement to this worldedness. Each of these are synchronic structures connecting our various modes and capacities of being into a multiplicity, one from which we compose all of our possible relations to the objects, places, people, 
cultures, and environments we inhabit. But Heidegger will now enlarge his breakdown by mixing in the dimension of time, or rather how we "swim", so to speak, through the aspects of time as something relevant to our practical relations. Ekstasis confirms the temporal engagement Dasein is indistinguishable from, so much so that the forms of being-in and taking-care-of are irrevocably revised to reflect the always already temporal nature of our practical commitments as human beings. Simply put, Dasein is always eksistence, an existence that stands outside of itself in one of several ways: it can reveal itself in modes of having-been, not-yet-being, or making-present. In this revelatory breakthrough, Heidegger is uncovering the primordiality of human existence such as it has been hitherto forgotten or concealed. By the same token, "Historicity" implies the range of cultures and the objects within and consituted by them, and an authentic historicity implements the understanding of ekstasis as outlined above: history would be understood not merely as an academic discipline composed of experts and artifacts worthy of study, but, alongside our ekstatic being, the fluidity of history moving through the past, present, and future.

After such a round explication of terms, certain assumptions now set the stage for the conflict of interpretations, as Paul Ricoeur has it, that will frame our reflections on trauma, memory, family, and self. Heidegger's understanding of human-being as temporally existential, hermeneutic, and factically determined is paramount for all cultural theory that succeeds him. Beyond this, however, his actual existential analytic provides a bevy of rich terminology by which to re-examine the conditions Anzaldua is subject to: something in Dasein's ek-sistence is being re-interpreted by both her predecessor's generations and her own; worldedness and the circumspect understanding 
that accompanies it has been shaken to the core by the travails of exile, colonization, and cultural trauma; and moodiness in terms of anxiety and something we could call "historicity-retention", the imprint of objects, memories, and places that have lost their reference to the living root of the worldedness they once belonged to; that are carried along tragically without the sense of place that begot them, solely within the memory of those last lonely survivors of an age. How can an interpretation of self, not to mention others, be compunded by the unavailability of linear foundations and essences, by a dearth of cultural reference that haven't been tainted by ontologically destructive practices (e.g. colonization)? Correspondingly, we will now examine the complications Jacques Derrida presents to selfhood, phenomenology, time, and writing, in his writings on differance, the trace, and auto-affection.

\section{Oneself as Temporal -- Differance and the Augenblick}

In two shorter works, "Differance" and "Signs and the Blink of an Eye", Derrida makes interventions into interpretations of self, time, and phenomenology that will further Heidegger's insights and stand in juxtaposition to our subsequent readings in trauma, testimony, and Anzaldua's auto-theory.

First we have Derrida's investigations into the nature of phenomenological analysis in Speech and Phenomena, his reading of Husserl's early attempts to ground a proper and fully functional eidetic phenomenology. Derrida's argument boils down to a diagnosis of the perils of Husserl's determinations, citing the realities of signification as an insurmountable barrier to the kind of pure self knowledge Husserl is bowling for in his own writings. To Derrida, Husserl is concerned with establishing a self-hood with 
absolute potential, the vehicle through which the discovery of essences in all intentional acts becomes actuality. In order to accomplish this feat, much of the empirical realm must be done away with, at least provisionally: "Self-presence must be produced in the undivided unity of a temporal present so as to have nothing to reveal to itself by the agency of signs" (Speech and Phenomena, 60) As Derrida points out, part and parcel of this reduction to a pure "seeing" is an elision of all signification and language -- a practical impossibility. Not only this, but a certain logocentric 7 bias, "a certain concept of the 'now,' of the present as punctuality of the instant, discretely but decisively sanctions the whole system of "essential distinctions." (61) This penchant for presence is a scab in the history of western philosophy Derrida will do his utmost to pick at, gnawing into its ramifications in all facets of discourse.

And it is this same tendency that stalks Husserl's interventions into studies on temporality in his "Phenomenology of Internal Time-Consciousness". Derrida's contention is that this metaphysics finds a new home in a philosophy of consciousness, specifically self-consciousness and its representation to itself. Somewhere along the line, this manner of thinking which is nothing more than arbitrary and historically designated, seized a hegemony for itself, and gradually slipped into our conceptions of self and world: our notions of time became saturated with the present, as it indicated "a nondisplaceable center, an eye or living core, the punctuality of the real now." (62) And this logocentrism now re-emerges in Husserl's trials for a pure phenomenological

7 The centering and privileging of "presence",as opposed to "absence", in metaphysical thought. What makes it ensnaring is its subtlety, and its conflation with truth itself, as Derrida describes: "Within philosophy there is no possible objection concerning this privilege of the present-now; it defines the very element of philosophical thought, it is evidence itself, conscious thought itself, it governs every possible concept of truth and sense." (62) 
method, one requiring a "solitary mental life" devoid of signification and outside of time for the completion of his reductions and the achievement of the analysis of pure essences.

A commendable goal indeed. Derrida does not leave much room for it, however, as he points out in typically deconstructive fashion how Husserl's formulation necessarily implicates an otherness -- namely, time and absence -- in any definition for the fully present moment. It becomes apparent that "The presence of the perceived present can appear as such only inasmuch as it is continuously compounded with a nonpresence and nonperception, with primary memory and expectation (retention and protention)." (64) If Husserl covets a perfect moment, one purified of all worldly and incarnate imperfections, then ideality will have to wait... literally. Time, memory, and otherness suffuse the stream of our conscious experience, and in fact render conscious/unconscious binaries at once more feasible and more doubtfuls. At the same time, the ideal godhood of an unblemished and self-assured method and perspective are quashed, or stalled sufficiently to obviate a particular sect of opinions and common sense conclusions. Representation (or Vorstellung, in the German philosophical tradition) is once again a battleground for competing points of view, ones not only mediated by discourse and language a la the premises of Cultural Studies9; but also,now, temporality and memory in the creation of one's identity.

8 Derrida pays due heed to the implications of these conclusions with how they interact with Freud's psychic theories: "It is no accident that The Phenomenology of Internal Time-Consciousness [sic] both confirms the dominance of the present and rejects the 'after-event' of the becoming conscious of an 'unconscious content' which is the structure of temporality implied throughout Freud's texts.

9 See Hall, Stuart, "Cultural Identity and Diaspora" 
In another famous essay, "Differance", Derrida evokes two similarly productive non-concepts: that of "play", and the eponymous "differance" otherwise characterized as "arche-writing". "Differance" and the "trace" are unspeakable words, unthinkable concepts, and anti-ontological philosophies. Derrida will repeatedly belabor the point of the notion's instability and anti-authority, and the need to think in a fashion radically different from tendencies towards mastery, autocracy, singularity, and control. He therefore approaches any and all descriptions towards understanding the term with caution, and a rigor that could be mistaken for bewildering indirectness or tomfoolery. If language, as Ferdinand de Saussure posits, is a system that precedes individual speech acts; that constitutes meaning not by independent positive significations, but through difference and the structural integrity of the system as a whole; that sustains this web of differentiation across present instantiations (synchronically) and across history (diachronically); and finds the sign, broken into signifier and signified, to be not a tough lump of connective tissue but a pliant and separable linking that is provisional through and through. These conclusions combine with Derrida's meticulous readings of Husserl and phenomenology to bring him to a startling discovery: meaning, according to Saussure's own premises, cannot be settled or bounded into a fixed locale. It cannot be completed in a single sign, being that difference and arbitrary connections belie that possibility; it cannot be recounted in a single utterance, as that meaning relies on countless as yet unsaid and unverbalized utterances, not to mention the innumerable histories that came before it; it cannot be found in the system at large, because the system itself is in flux and too global to be reduced to a particular assertion or objectification; and it cannot be outsourced to metaphysics, philosophy, religion, or other variations on 
transcendental signifiers because these themselves are mere facets of signifying practices, and who moreover represent logocentric ontologies that contradict and even erase difference and deferral as conditions for life, existence, be-ing to be possible.

As for the term itself, differance points to, implies, and suggests the character of signifying acts and our temporal being through a performative gesture: enacting the quandary that broaches all of the aforementioned realizations in a single letter, the " $a$ " in "differance". Derrida relates how the word is practically unrepresentable in French speech, the "a" and "e" scarcely distinguishable to most listeners; this present/absent distinction stands for the "trace", the evanescent flow of meaning between signs and sign systems. The modification also references the fact that writing, the byword for lack of presence and the voice, actually turns out to be better at conveying the difference. Finally, a duality of difference/deferral is alluded to, one that spotlights a critical factor of the theory of meaning:

In constituting itself, in dividing itself dynamically, this interval is what might be called spacing, the becoming-space of time or the becoming-time of space (temporization). And it is this constitution of the present, as an 'originary' and irreducibly nonsimple... synthesis of marks... that I propose to call archiwriting, archi-trace, or differance. (Margins of Philosophy, 13)

Derrida here connects the spacing that becomes visible on the page, the negative space and allegedly non-signifying articles and punctuation, with a theory of signification, claiming that it is precisely these absences of meaning that must obtain if any meaning is to exist at all. He is pointing to how meaning is neither the presence of pure signs nor the absence of nothingness, but a trace that proceeds indefinitely and sans eradication, that always prevails and that makes our languages exactly what they are. He alludes to a 
cross-contamination, an interbreeding of time qua space and space qua time as another instance of our ontologies failing to make sense of the complex phenomena that undergird our very existences: language makes meaning via difference, a spacing going on between signs; but at one and the same time, meaning is being generated by deferral, by the time-lag necessary for one sign to not be crossed up by another. And both of these movements must take place, so much so that they can become inseparable in our conceptions, beyond the binary that concealed their wonder and unfathomability.

When it comes time to outline "play", Derrida makes reference to just these aspects of "differance" that constitute the movement or refraction of meanings that protract delivery, that forestall conclusions and closure with a flickering of signification in between and among positive terms rather than inherent and whole in any single one of them. He specifies two qualities of "play" in particular, the strategic and the adventurous:

In the delineation of differance everything is strategic and adventurous. Strategic because no transcendent truth present outside the field of writing can govern theologically the totality of the field. Adventurous because this strategy is not a simple strategy in the sense that strategy orients tactics according to a final goal, a telos or theme of domination, a mastery and ultimate reappropriation of the development of the field. (7)

Without transcendent signification nor the teleological guidance-hegemony it entails, "play" or "playfulness" involves reading and interpretation as matters of discovery, of chance and blind fate, of entropic madcap foolery or jest, all because there is no higher order with the final say or dictate to govern over us by. While the coltish ramifications of such a decision might be the most apparent, the socio-political consequences for a determination of self/collective identity are just as stark: no matter what transcendental signifiers we might lean on (God, Country, Family, Law) the fact of the matter is all 
identity formations will trek through morasses of ambiguity and nothingness over which their signifiers will endeavor to create meaning. And the point, if there is one, is that the nature of this stumbling is evolutionary, flexible and non-static, and that the adventurousness and playfulness always already rejects teleology and transcendental origins. Thus the creation of identity, porous and fluid as it is, means that it is through gaps and spaces that meaning is created, and that new ontologies of self and community are born.

So if the self is not whole in any present moment, it is because its process in time, as an inhabiting of time, constructs its edifice, or paints its portrait. While seemingly selfevident, common sense conclusions and readings of various phenomena still persist in privileging the present moment, the Augenblick, in representations of the self to itself: it will become apparent in conflicted readings in psychoanalysis and trauma theory, and perhaps be reborn in a religio-metaphysical commemoration in the auto-theory of Gloria Anzaldua, a re-writing of the self always already in progress but in tribute to its cultural memory. Where Derrida leaves off and Anzaldua begins is in the praxis of this recreation, the application of writing as chisel to the marble of the self, elevating play to an affective and emotionally poignant crescendo, and paralleling the spiritual as an embodied and practical engagement with worldedness that expands meaning into a dialectic between oneself and one's Lebenswelt. It is in her return to cultural memory and religiometaphysical roots that Anzaldua grounds her being and her traumas in a collective past, while still allowing for an embrace of an openly mestiza future. 


\section{Trauma Studies and Psychoanalysis}

With our presuppositions about temporality, selfhood, and worldedness set up and buttressed, we continue on to the foundational premises of literary trauma theory. Immediately capturing our attention is the work of Cathy Caruth, Shoshana Felman, and Dori Laub, all of whom are accredited with inaugurating the discipline of trauma studies in the United States. All of these thinkers share a view that is decidedly more poststructuralist in sympathy than a discourse arguing for and articulating concepts in the literature of trauma would apparently warrant at first sight. In fact, all of these thinkers owe at least the lion's share of their insights and foundational assumptions to the work of Sigmund Freud, Jacques Lacan, and Jacques Derrida. As we have already unpacked the significance of Derrida with respect to temporality and the self, an inquiry into psychoanalysis via Freud will open an adjancent field of analysis; questions on the nature of traumatic memory and recall, of the objects represented in the dark hollows of individual psyches, of the affective responses characterizing a painful recollection, and of the repetition (or otherwise resolution of) the referent experiences and their correspondent hang-ups.

The psychoanalytic contribution to literary trauma studies is reducible (for our purposes) to a few notable examples and their subsequent reinterpretation by the inaugural generation of self-styled trauma scholars. Freud's most influential and resonant conceptual advances came in Beyond the Pleasure Principle (1961, Strachey), the book which Cathy Caruth would later take up as one of the foundational texts in trauma theory. Freud comes to the question in the wake of numerous patients, all recent veterans of the first World War, appearing with new symptoms and neuroses: flashbacks, anxiety, 
nightmares, insomnia. Freud identifies these as "war neuroses", a condition subsidiary to the more generalized "traumatic neuroses", attributed to victims of life in the trenches on the Western Front. His intention in writing Beyond the Pleasure Principle is revisionary, to make the facts of traumatic symptoms in veterans square with his theory of dreams, to wit the recurrent nightmares of a patient reliving their instance of traumatization with what he had repeatedly referred to as the "pleasure principle" operating in all conscious states. To Freud, human psyches retained their state of equanimity as one that was immanently pleasurable, a constancy they would always strive to return to. Pulling in the other direction, however, is an equally constant and potent excitation from the external world, much of which the ego cannot withstand and is always teetering on the brink of being overrun with. Mental events are "invariably set in motion by an unpleasurable tension, [] that [] takes a direction such that its final outcome coincides with a lowering of that tension — that is, with an avoidance of or a production of pleasure." (Freud, 3) It is this regulation back to the norm or the mean that defines the "pleasure principle" — and its temporizing correlate, the "reality principle", a rule permitting a deferment of the ultimate pleasure for a short period. But it is the "repetition compulsion" Freud observes in his patient's waking activities and nightmares which disturbs the neatness of his initial reading, and is what compels him to reconfigure his theory to make room for significantly more difference. The "death drive" is this postulated factor, the one which upsets solely positive interpretations of the human psyche and introduces a psychic drive intent on disruption, and disassociation, from the conscious ego; the unconscious, as it turns out, contains instincts directed by both pleasure and self-annihilation. 
Later, and in a quaint analogy, Freud compares the threshold of consciousness and the external world as a membrane to those found in single-celled organisms. The membrane's threshold comprises the perceptual consciousness, the outer shell of the human psyche responsible for perception. But that isn't the whole story, as "Protection against stimuli is an almost more important function for the living organism than reception of stimuli" (emphasis original, 30). As the outer frontier of psychic systems and furthermore one equally regulated by the pleasure principle - the whole structure of conscious thought has, invested in its very topography, an interest in preserving a balanced state of pleasure/unpleasure, with excitations borne in from the outside world being a prominent source for the latter. And this is precisely the site where traumatic experience occurs: Freud speculates that those experiences which we could designate as traumatic are caused by "any excitations from outside which are powerful enough to break through the protective shield." (Freud, 33) These breaches have only one possible response, in his mind, which begins immediately following the interpolating attack. The psyche endeavors in "mastering the amounts of stimulus which have broken in and of binding them, in the psychical sense, so that they can then be disposed of." (33-4) The whole problem as Freud sees it lies in a low cathexis (a system underinvested with libidinal energies) at the breached site, rendering the subject vulnerable to what he refers to as "fright", the characteristic response of surprise and unpreparedness.

Understood in concert and in context, the pieces of the puzzle now begin to fall into place. Freud now has the tools to explain the nature of traumatic nightmares, and their place in his system: they are repetitive attempts to "master the stimullus retrospectively, by developing the anxiety whose omission was the cause of the traumatic 
neurosis." (Freud, 37) These dreams are not functions of wish-fulfillment and the pleasure principle, therefore, but rather more promordial and fundamental re-structurings of the psychical architecture on the level of the integrity of the ego as such, a reconfiguration of cathexes following a dramatic and damaging oversight in the psyche's distribution. The repetitive character of traumatic nightmares is the performance of such restructuring, and the anxiety they produce is, with respect to the fabrication of a new ego, the "intended" outcome of preconscious processes and the dream-work.

Unpacking Freud's propositions in Beyond the Pleasure Principle makes for a thought-provoking and needle-moving entrance to an entire discipline (psychoanalysis). But the conceptual deluge calls for something of a step-back, a bigger-picture survey of the field as it currently stands in reference to critical controversies and the field of literary studies as a whole. Trauma studies, in its original iteration, is a product of a small coterie of American literary scholars convening out of a complex of shared concerns. Cathy Caruth, Shoshana Felman, Dori Laub, and Geoffrey Hartmann are cited by Stef Craps and Lucy Bond in their monograph Trauma (2019) as founding members of a resurgence of interest in the topic. All of these theorists (with the exception of Laub, a practicing psychotherapist) were members of the so-called Yale School of Criticism, specializing in an Americanized brand of deconstructive readings inspired by Jacques Derrida. By Bond and Craps's estimation, the Yale literary trio became interested in trauma as part of "an effort to redeem and rehabilitate a mode of criticism that had fallen out of favor" and "the reinvention in an ethical guise of an embattled paradigm" (Bond \& Craps, 52). There is a grain of truth to their sideswipes at the legacy of deconstructive literary theory and criticism, and its worst abuses as an ahistorical doctrine flimsy in its resolutions against 
fascistic tendencies even among its adherents. But what deconstruction does bring to the table is in Derrida's rigorous critiques of logocentrism, binaristic thinking, and the presence of self and meaning, the utility of which extends into the reading of literary texts and beyond.

And the Yale critics were more than keen to pick up on the trails left behind in Derrida's wake. The ethical turn in literary studies characteristic of the mid 1990s appertained most viscerally for trauma studies in the way that it copes with the legacy of the Holocaust and its victims/survivors. Most of the enduring polemics endemic to literary trauma studies spring from questions related to managing the memory of what struck the Jewish people in Europe during the 20th century: What becomes history, and who gets to decide? How can we adequately and conscientiously represent an atrocity so far in the distant extremes of enormity? How, indeed, to make comprehensible something so incomprehensible to an age of scientific progress, (relative) economic prosperity, and the highest advances of "Reason"? What can art hope to stand for when cowed by such senselessness? And what about those who felt the corporal punishment, where directly disciplined, coerced, confined, brutalized, and finally murdered by the abbatoir that was the Nazi regime? What is the nature and borders of traumatic experience according to the travails of those who survived this onslaught? And how ought those listening to their testimonies bear appropriate witness? Should the survivors themselves be dwelling responsibly in past anguishes, or surpassing them?

It is from this monumental catastrophe of the 20th century that the field by and large sources its raison d'etre. The two vectors worth plumbing — the moment of traumatization, and the testimony and bearing witness that circumscribe it - are each 
explored in their distinct ramifications by, respectively, Cathy Caruth and the pairing of Shoshana Felman and Dori Laub. Caruth's approach is both more literary (i.e. more fundamentally applicable to our primary texts) and more directly affiliated with the intersection of psychoanalysis and deconstruction thus far explored in this paper, and so will be treated first. Felman and Laub, as well as numerous secondary or minor figures in the fields of Trauma, Memory, and Holocaust studies, will figure more as supporting theory due to the comparative limits of these fields to the subject matter of this thesis.

Cathy Caruth's Unclaimed Experience is a landmark work in trauma studies, its publication representing the induction of many precepts or guiding questions/concerns the field now takes for granted. As already mentioned, Caruth's worldview incorporates deconstructive traits into a psychoanalytic reading of traumatic representation, experience, and recall, homing in on the distinct problematic of the uncertain and the unknown coextensive with the acts of wounding and being wounded by our pasts. These notions all stem from the analyses Freud produces in Beyond the Pleasure Principle, with certain salient differences. For one, Caruth is less concerned with restricting her interpretation solely to the instances of repetition. Where Freud sees the re-enactment, over and over again, of the conditions inducing the traumatic neurosis in order that they may be superseded, Caruth also discovers an ethical component, an intersubjective imperative contained within the repetition compulsion that holds within it the fountainhead of witnessing and ethics themselves. The figurative trope she makes use of is the "speaking wound", an image which points out the dilated response and corpotemporal division between the knowing and not knowing attendant to those whom have been breached by a traumatic experience. 
Caruth agrees with Freud that trauma is brought on by a sudden influx of intrusive stimuli; their difference lies in the subject's response to this moment of crisis. As we have seen, Freud's position seeks to explain anxiety, repetition, and nightmares, leading him to postulate a death drive manifesting as a compulsion to repeat self-destructive behaviors. Caruth is, as we have outlined, of the camp favoring an intersubjective reading of Freud: she sees the trauma as fundamentally about relation with another, a matter irreducible to just the inner psyche. It is because the wounding is caused by trauma, by the surprise "accident", that it catches the subject unawares and does not become "available" to consciousness until it sprouts up in dreams and neuroses. (Unclaimed Experience [UE], 4). In much the same way as the originary moment of transcendental knowledge becomes elusive to Husserl as Derrida reads him, and the kernel of human nature escapes the grasp of the history of western philosophy, so too is the traumatic experience never quite incorporated by the survivor: "...Trauma is not locatable in the simple violent or original event in an individual's past, but rather in the way that its very unassimilated nature -- the way it was precisely not known in the first instance -- returns to haunt the survivor later on." $(U E, 4)$ Caruth highlights the impossibility of the survivor's absolute and transparent knowledge of the event they return to again and again — as it is exactly for this reason that their fixation on the moment occupies their dreams and nightmares. Her reading has it that the relation from survivor and event is not one-to-one, never a direct reference but one interpolated by the dilation of temporality. Caruth would designate this stretching of time in traumatic remembrance "latency", describing how "the experience of trauma. . would thus seem to consist, not in the forgetting of a reality that can hence never be fully known, but in an inherent latency within the experience itself." $(U E, 18)$ Caruth is 
making a point not dissimilar to the one Derrida makes in Speech and Phenomena: the experience of oneself is, structurally speaking, not identical to the originary moment of consciousness, but displaced in time and space as a flow away from that origin. But while Derrida is arguing for the primordiality of this experience, Caruth differentiates the traumatic moment as one that brings to a halt part of the temporalizing process of beinghuman/Dasein, that retains the pastness of a bygone event in making-present in a fashion disruptive to linearity in personal histories. In much the same way, the argument's conclusion disposes with pure representation of self to oneself, or of self to other, replacing purity with contingency, uncertainty, and dispersion.

As directness is absent from the survivor's own full knowledge of themselves and their experience, then the witness cannot hope to know it in any fuller sense than the bearer of that burden already does. But listening is not out of the question; indeed, it is more vital than ever. Relation is transfigured into that of the "speaking wound", the histories of self and other contained within trauma's echoes that reveal identity, history, narrative, past. And all this concealed, veiled over, in a survivor's testimony, itself necessarily more akin to literature and poetic language than literal representation. Understanding trauma is not then simply a matter of pathology or curable disease: the wound speaks to us, tries to address us "in the attempt to tell us of a reality or truth that is not otherwise available." (UE, 4) Acts, intentions, language, and signification stemming from a traumatic event thus represent the unknown and unknowable to ourselves and others, and these show up in the most mundane and routine acts, or in our darkest moments. 
Caruth's demonstrations echo her sentiments; they have the ominous aura of the intensely unknown. Faithful to ethical implications in the poststructuralist tradition as announced by Levinas and then expanded by Derrida, Caruth points out the aporetics native to trauma: the wound's primordial cry towards an imperative, despite its obscurity; its displacement into the external and other, even while it overflows its borders into every part of the survivor's lived experience; and perhaps most markedly, in the very structure of its (non)occurence, of how trauma consists in "a repeated suffering of the event, but it is also a continual leaving of its site." (Trauma: Explorations in Memory [TEM], 10) Taking account of these disparities and the uncertainty rife in any enterprise set on making sense of the senseless becomes paramount. If traumatic testimony addresses both what is consciously spoken and unconsciously transmitted, then only a reading practice sensitive to the contradictions wrought when individual and collective, remembered and forgotten, repeated and revised lose themselves in their counterpart. The condition is shot through with paradox, so its solutions must embrace the same if they are to speak the same language.

Missing from this account, however, is a praxis of self: Caruth's theorems are, phenomenologically speaking, not undertaken as one subjected directly to the trauma in itself. While a fair portion of her innovation is in deconstructing the full logos of the traumatic event in the survivor's pysche and dispersing its meaning into relation and otherness, the privileged locus of testimony has not changed. It is thus a fair and necessary criticism to suggest that Caruth is discussing more of a structural condition of traumatic narratives, experience, and healing, than propounding the concrete particulars of what actual resolution and convalescence would look like. Her position is indeed vital 
for reception of testimony, but she falls short when it comes to therapeutic or healing practices. An interesting fact, as her reading and interpretive strategy still lends itself to understanding the first-person and descriptive procedures of as Anzaldua will take it up. Caruth favors a more narratological and experiential rendering of the lived particulars of trauma than an orthodox psychoanalytic or psychiatric perspective: "Rather than straightforwardly describing actual case studies of trauma survivors or attempting to elucidate directly the psychiatry of trauma," she clarifies, "the chapters that follow explore the complex ways that knowing and not knowing are entangled in the language of trauma and in the stories associated with it." (emphasis mine, Caruth, 4) Fittingly, Caruth is preoccupied not with breaking down the structures of traumatic experience into scientific codes, but with resisting such an impulse to knowledge while underlining the specificity and unassimilability of both the experience for the survivor and their testimony for the witness. To this end, she sets out to explore the language and narratives surrounding these experiences from a concretely first-hand perspective - that of her bearing witness as interpreter to the examples she picks out of literature, film, and theory. All of this is to suggest two conclusions: that Caruth's methods and ends are more markedly phenomenological and deconstructive with their eye towards lived experience, phenomena over conceptual coagulation, and the ethics of bearing witness than perhaps they are purely psychoanalytic; and that a theory of trauma elucidated by the victim themselves could perform the dual function of relating the unclaimed experience (and thereby claiming it) and simultaneously moving towards resolution within this act of bearing witness to their own unrecognized past, while simultaneously proposing their testimony to be corroborated by another. The clash of both imperatives - to listen 
attentively and cautiously; to reconstruct narratives for one's own purposes — is the painful, mournful, rending act that phenomenology and psychoanalysis wrestle with, and that Anzaldua recreates in her onto-spiritual self-rendering styled as the "Coyolxauhqui Imperative", a queer deconstructing of what could be read as a false binary of listening/speaking. This species of theorizing — what we might call "auto-theory" — is precisely what my readings of Gloria Anzaldua's work will come into contact with, and will endeavor to develop as a previously under-interpreted aspect of Anzaldua's thought as an effort to literally inscribe the darkest of demons into one self.

There must always be undiscovered abodes of memory, history, being, and a pattern of traumatic experience and recall is no different. Caruth, paraphrasing Lenore Terr, herself proffers the idea that "there may not be one simple, generalizable set of rules that can determine in advance the truth of any particular case, and we may thus ultimately have to struggle with the particularity of each individual story in order to learn anew, each time, what it means for a memory to be true." (TEM, viii-ix) This same struggle transfers itself, moving beyond a concern for the self in traumatic survivors and toward, as implied by Caruth's proposition, a prerequisite for a conscientious witnessing writ large. Shoshana Felman and Dori Laub will answer the call for such a form, and in the process lay the foundations for a healthy respect of difference - in race, class, gender, and so on — in trauma theory as a field.

\section{A Crisis in Witnessing}

Shoshana Felman and Dori Laub's seminal Testimony: Crises of Witnessing in Literature, Psychoanalysis, and History revitalizes an important and hitherto underserved 
side of the ideas explored in this thesis: what does the process of listening-to, interpreting, receiving, reconciling, and accepting the personal stories of one's loved ones look like? What are the cracks in the methodological pavement to be avoided, and where reside the dead-ends which lead the listener only to regressions in understanding the speaker's testimony? And what is the role of — or the centrality or the marginality of factuality, history, and truth vis-a-vis affect, interpretation, faith, and trauma when it comes to performing the act of witnessing?

Felman opens the problematic with a few key concerns: what is testimony as it relates to culture, memory, history, truth, affect, and trauma? Any answer to this set of questions must, to her, begin with a wonderment embedded alongside an uncertainty, an openness towards difference and the unknown: "This is a book on memory and on questions. On questions that we do not know, that we do not as yet possess as questions, but which nonetheless compellingly address us from within contemporary art and from within contemporary history." (Felman \& Laub, xiii) Jointly with Caruth, Felman extols the virtues of literature and its powers to contain the testimony of a pain, a wound, that resonates with an ethical imperative. She and Laub further this idea by adding their reflections on the ways that not only a listener must treat and embrace the act of bearing witness, but how the very conditions of testimony are problematized.

Felman's chapter Education and Crisis, Or the Vicissitudes of Teaching, documents the process and renewed understanding she underwent during a graduate seminar she taught at Yale. Her aim? To demonstrate the ubiquity of testimony in all genres of writing, while coaxing out an understanding of the encounter with strangeness that thinking about testimony proposes to a wider readership. Upon closer inspection, it is 
the vitality of that uncanniness that inspires the witness to their listening, and the writer or speaker to their expression. There is something about this relation, Felman argues, that resembles a "trial", at which one or another — writer, artist, poet, survivor — is "appointed" to speak their part at the witness stand, to pass on the details and minutiae of their experience in order to record this horror, this perturbation of our reason we call existence (Felman \& Laub, 2). The most effective manifestations have the distinct and unusual property of imbuing themselves in their totality into their listener, their reader, their witness. Felman refers to these as "life testimonies," something that is "not simply a testimony to a private life, but a point of conflation between text and life, a textual testimony which can penetrate us like an actual life." (emphasis original, 2) In other words, the signifier that is the text has so approximated, so integrated itself into its signified (the lived experience, the author, the meaning) that for all appearances the reader/listener receives the embodiment of that life through the text. While poststructuralist criticism has already apprised us of the significant and unbridgeable chasms lining the transmission of meaning in speech, writing, and language, the powerful experiences Felman describes stand apart; As Derrida explains, it is exactly the impossibility of exact relation that compels the exhortation to bear witness, to have faith, to inaugurate the ethical.

Another way to note the same idea is through the discernible connection between the individual and the collective, one of several contradictions spanning the condition. The Appointment (what makes one a witness?) is how Felman arranges and frames this double bind: one is compelled to speak out of a duty, out of an imperative to report on crimes or traumas no one else is available or capable of speaking to. It is a "solitary 
burden" (3), yet one the witness is simultaneously impelled to break out from, reaching out to others who would listen. These ethical conclusions sprout from a historical moment, one that seems to have morphed into a hotbed of testimonial literature with the tide of the mid-20th century catastrophes of the two World Wars. Felman terms this a "crisis of truth", comparing the larger predicament to one faced in the everyday setting of a courtroom, one where witnesses are routinely brought to the stand when all other evidence-gathering methods have failed. The resonances for our purposes are clear: what is the role of the speaker, the one charged with transforming the unspeakable into something to be channelled to others waiting to listen? What does the act of testifying mean for the witness, and what does it mean to those just as impossibly burdened with setting the stage for them to bear out this testifying?

Returning to the psychoanalytic model brings to light some of the qualities immanent to this office, specifically in the context of the knowledge of self through memory, time, and trauma we've already reviewed. Felman highlights precisely the dialogical schematic in psychoanalytic discourse — and, more importantly, its clinical practice — which facilitates the discovery and understanding of previously untrodden regions of oneself. This dialogue has revolutionary potential, as she points out: it is, fundamentally speaking, the revelation of unconscious testimony and the process unveiled by the analyst, one in which "the doctor's testimony does not substitute itself for the patient's testimony, but resonates with it." (15) These conclusions are in line with findings so far evident from Caruth, Derrida, and Heidegger: the self, unwound across time, and its dearth of simple resolution with itself in any nugget of momentary and divine clarity. After all, Freud (as Felman reminds us) always believed in the fact that "it 
takes two to witness the unconscious" (emphasis original, 15) and part and parcel to a rethinking of testimony is a rethinking of ontology, of seeing human-being as incomplete and in progress, neither a plenitude nor a self-sufficient nucleus. Implications from such a basic restructuring are always far-reaching, a domino-effect:

that one does not have to possess or own the truth, in order to effectively bear witness to it; that speech as such is unwittingly testimonial; and that the speaking subject constantly bears witness to a truth that nonetheless continues to escape him, a truth that is, essentially, not available to its own speaker. (15)

What we learn at last is in the relational and ethical claims to self-knowledge, and its links to speaking, writing, and interchangeability with others via testimony. These are confirmations and extensions of time, history, and its ruptures as we have thus far examined them, and yet also incorporating personal and individual affective responses to the wider historical threads and contexts they are encountered in. A self unburdened from transhistorical essences is similarly disabused of requirements for transhistorical truth; or, to put it another way, once the witness to trauma (and the witness to this witness) shed the onerous strictures of historical consistency and fact, the way is open for a closer listening to the scars laid upon the bodies and texts (and bodies-as-texts) each witness represents, and to a historiography less dismissive and more appreciative of subjective testimonials and their truths.

Dori Laub brings expertise in clinical psychiatry and psychoanalysis that complements the literary and narrative theorizing Felman conducts for her part. He walks a fine line, theorizing a clinician's perspective on traumatic life experiences and the road to recovery, without overly pathologizing and while abstaining from retaliatory judgment. His is an approach, therefore, laudable for its ethical commitment, something more 
common and more easily imaginable from someone who has either personally or at a single remove dealt with similar events to what they are treating their patients for. Laub's contributions echo and further Felman's, in particular the description of testimony as a procedural form of knowing, a creative act inscrutable to its speaker until it is spoken. His inferral from this premise is about the equally vital role of a listener, a witness to the event of emergence without which the act remains unheard, and therefore unmotivated to be spoken in the first place. He asserts that "the testimony to the trauma thus includes its hearer, who is, so to speak, the blank screen on which the event comes to be inscribed for the first time." (57) So testimony can only operate in its healing, redemptive capacity if a place exists for its reception — a reception meaning an acute and sensitive listener.

The fact of the request for a listener, moreover, as opposed to an "objective" space attests to the humanism of the problem. Matters of objective fact and record are not at issue, but the very felt and incarnated record the witness provides, the subjective truths and, more importantly for our purposes, worlded historicity they carry that is our concern. Laub sketches out an anecdote of a Holocaust survivor's testimony about an uprising at Auschwitz, and its skewering for historical innacuracies by scholars at a conference. While busy sniffing out errors and discrepancies in her testimony, the scholars were missing a crucial fact of their own: the survivor was telling the story not of exactly what happened, but of how the prisoners felt and what the uprising meant to them. Reading for the concrete expressions of trauma and memory through affect and meaning has a categorically different end in mind, one that privileges the survivor and human being as the locus of history and recovery. 
If what pertains to our study is complexly subjective rather than purely objective, then the observer must announce and process their own subjectivity in relation to it. There is no longer any impartial standing, any dispassionate position, to conceive of. If truth hinges on the fragile expressivity of a survivor and the tandem embrace of a listener, the stakes become much higher — not least of all for the listener themselves. The second witness to the event, and the conduit through which the victim pours their story, are in a real sense party to the anguish of the survivor, feeling "the bewilderment, injury, confusion, dread and conflicts that the trauma victim feels." (58). When woefully undertrained or even unaware of the impacts inherent to the role, listeners (whether social workers, psychiatrists, or loved ones) subject themselves to the marginal after-effects of their traumatized counterparts, like looking too closely at the sun.

In order to stave off this type of secondary traumatization, "The listener, therefore, has to be at the same time a witness to the trauma witness and a witness to himself." (58) Laub's observation opens a path to a proper account of traumatic breaks and their remedies as surpassing the borders of any one individual, and incorporates a notion not only of selfreflexivity but of expressivity.

And the extension of these borders bears out in the spread of catastrophe, a lingering complex of micro and macro inflictions and re-inflictions of pain attendant to the original moment. Laub outlines cases in which, for example, a survivor has gone on to repeat or otherwise suffer a copy of the trauma in their later lives by virtue of the memory's suppression over a long period of time. Laub's pictures of patients that have lost homes, careers, and even their entire families in the decades subsequent to the event demonstrates "The continued power of the silenced memory", and how it "finds its way 
into [his patient's] lives, unwittingly, through an uncanny repetition of events that duplicate — in structure and in impact — the traumatic past." (65) The very compression of the memory within brings about violent internal stirrings, an upsetting of vitality from the inside out with aftershocks emanating - in another demonstration of their extent to the survivors children and even grandchildren. He describes the metaphor of a "black hole" in memory, a structure of denial and nihility at the center of where most children seek the memories of their parent's childhoods and upbringing to be bequeathed to them as part of understanding their personal histories. In survivors of extreme trauma, the silence - whether mute or displaced in glib distractions — becomes a new source of pain, one where the children must struggle to fathom their origins in order to recollect the futures disguised within them. This recovery is virtually a matter of life and death for the second generation, for which the structure of memory itself is at pains of collapse so long as their predecessors keep the deep recesses of the past in a straightjacket. It is therefore why Laub considers the "the place of the greatest density of silence" the same one which "paradoxically becomes, for those children of survivors, the only place which can provide an access to the life that existed before their birth." (64-5) If resolution is viable, or even possible, it will reside in the twisted knot at the heart of every subsequent upset, pang, and multiplying wound that continues its scarring effect. And the lives touched by the fringes of this wound will feel the inverse imperative, to dive headlong into their patrimonial traumas and clear the way for a renewal of memory and history.

As has become evident then, the act of witnessing encompasses more than the lonely self and sufferer of the traumatic memory, and bears trenchant repercussions for those unwitting participants to its hurt. What, then, would a possible recovery consist of? 
Some jeopardy lies in wait for those less wary of where such an endeavor can go awry. As we have seen, all hangs on the quality of listener. What comes next depends on circumstances, but a potentially disastrous result betokens the larger risks of bearing witness: the recurrence of traumatization. A miscarriage of either the telling, where "the price of speaking is re-living" (67), or in the listening, where "the absence of an addressable other, an other who can hear the anguish of one's memories and thus affirm and recognize their realness, annihilates the story" (68) both conclude with a mere repetition, if not downright exacerbation, of traumatic anguish. What constitutes the correct approach in such a situation? Returning to the fundamentals of the traumatization process provides some clues, while preventing any straightforward answers to the difficulties we've so far enumerated.

The cross-pollination of ideas between Laub, Felman, and Caruth is manifest here once more, as Laub circumscribes the structure of trauma as something taking place "outside the parameters of 'normal' reality", making it "an event that has no beginning, no ending, no before, no during, and no after." (69) Here is a differently nuanced position from Caruth's, for whom the traumatic event is fundamentally mis-experienced and forever lost to conscious perception, to be recalled indefinitely and without resolution. Laub differs slightly in opinion in his determination that the traumatic is utterly without reference, devoid of comprehension, and beyond the scope of everyday language. But his true distinction is in articulating a methodology, a plan of escape, for the turmoil of such apparently perpetual internal strife. In what he terms "re-externalizating [sic] the event", an exit by way of compromise is proposed, a light at the end of the tunnel for survivors involving the grueling act of re-telling in order to exorcise the memory. In projecting the 
past out into the world, a return to communal time is effected for the victim's inner bounds, "a reassertion of the hegemony of reality and a re-externalization of the evil that affected and contaminated the trauma victim." (69). The texts of trauma, therefore, can be read as efforts of testimony or of bearing witness, as they are in principle the manifestations of self-remedy.

While Laub is referncing traumas native to an existentially apocalyptic event, some of his insights are still transferable to structures and happenings less extreme, albeit still shocking, to their victims. We can take this position without too much constraint if we consider the larger view of their project as propounded by Felman in the book's preface. Their actual interest, broadly speaking, is in "the meeting point between violence and culture, the very moment when, precisely, the phenomenon of violence and the phenomenon of culture come to clash — and yet to mingle — in contemporary history." (xiii) The downstream effects of violence on culture, interpersonally and at the familial and society-wide levels, has wider ramifications and applicability. Still, Caruth's words loom large: there are as many ways of treating a traumatic memory as there are traumatic memories. Our methodology ought to be adaptive to this fact, less of a rigid structure which risks displacing the traumatic narrative and causing active violence to the testifier in the form of re-traumatization. Laub would agree — and he points to the instances of re-traumatization associated with the failure of the witness to furnish a kind, attentive, and composed act of listening, which includes cultural sensitivity and awareness. A process speaking and writing from within the same or an adjacent cultural perspective would better prepare us to make sense of traumatic narratives. The flip side of a minority view is in not essentializing either larger cultural constructions as hegemonic (i.e. Latinx 
over disparate national identities) or generalizing an individual's perspective into a global one. These will be our problematics as we enter the analysis of Gloria Anzaldua's work, a theorist and thinker whose ideas will ramify and bind our readings in psychoanalysis and literary theory into a concrete theory that will consolidate and synergize them all.

\section{The Phenomenology of Trauma - Anzaldua (Un)Bound}

Our question, when redirected at a writer, thinker, poet, activist, feminist, Chicana, and lesbian like Gloria Anzaldua is, in a certain light, the question regarding why I chose to sketch out her identity, her self, her being, with the sequence of identifiers just listed. These do not exhaust the categories Anzaldua situates herself within, nor the labels she co-opts in her works. And indeed the plausibility of either categories or labels as notions sufficient for the delineation of a person or individual is vehemently questioned by Anzaldua, her ontology of self being in this respect aware of Heidegger and Derrida's anti-essentialisms. But a plumbing of the depths, the riches, that Anzaldua's work offers to this project could begin by asking not why she has come to determine herself, albeit provisionally, with various intersectional positions, but how she came to this determination and how she continues, in her writings, to re-evaluate and recycle the past-into-present, and the present-into-future. The usual apprehensions may accompany such questions: what's the use of talking about the ordinary, the mundane? Simply put: so that we might break free from what makes it ordinary, and rediscover the radical implemented in our most primordial activities; So that we may unearth once more the distinction between philosophy and poetry, theory and praxis, and craft a third space incarnated from our deepest memories and most resonant stories; So that we may better 
comprehend and appreciate the re-processing of writing and how its ripples extend to an expansion of self and identity in what Homi Bhabha terms the "locations of culture". In short, Anzaldua's texts stand to influence thinking about auto-theory and auto-biography, and her contributions towards its evolution into a new stage of less past-thinking and more creative forward-thinking production; a production, we might venture to suggest, that will set the stage for our understanding of a new subculture's reclamation.

Any reading of Anzaldua's work must begin with the titular concept of the "borderlands". Just as common an approach to understanding such borderlands is through geography, a set of situational assumptions derived from Anzaldua's subjective placement on and around an actual physical border (The U.S. Southwest's abutting Mexico itself). This however would be a mistake. As Anzaldua clarifies in her preface to the book itself, the geography is secondary to (or at least distinguishable from) the "psychological borderlands, the sexual borderlands and the spiritual borderlands [which] are not particular to the Southwest." (Borderlands, preface) What actually interests her are the frictions, the torsions, the points of contact where the rubber of one culture or mindset meets the road of another. And these clashes, in turn, re-present themselves in physical space. The process resembles a hermeneutic circle as Heidegger would see it, one without clearly defined levels or margins and with many entrances and exits. Most importantly, the figure allows for an ambiguous and anti-foundationalist thinking that does not require something of the logocentric preference for origins to intrude; for our purposes, the chicken-or-the-egg conundrum of body/psyche/world is resolved by Heidegger's resonant description of being-in-the-world, and the equiprimordiality of self to one's factical circumstances and vice-versa. And Anzaldua takes up this formulation, 
as she often describes the distinction between body (i.e. both the corporal self and the material world) and mind (i.e. the thinking self, consciousness, and spirituality or the metaphysical) as an illusion, if not an altogether malicious scheme of heterosexist Western thinking.

The primacy of this particular facet of Anzaldua's theory points to her materialistic conception of reality and the deep connection of self to culture, history, and place. While she is through and through a spiritual writer and being, there is one side of her that is undeniably steeped in the physical world. Our interests will be in this region of her ontology, as it draws a direct path from geopolitics to self to culture to history and back again. So, for example, Anzaldua herself stands atop the historical frontier and site of imperialist power-exertion par excellence, the American Southwest, and embodies a variegated identity derived from the very factuality of those border tensions; the mix of languages (Spanish, English, Indigenous languages, blends of two or more of each) she uses, her class position, her racial background, and her spiritual modes all derive from one or more clashes, breaks, and fusions born from imperialist practice and resulting in hybridical identity.

A discourse, a web of signs, overlays the phenomenon of border culture, one in which power relations encode the very relation of self and other into the land itself. The nature of borders is, according to Anzaldua, "to distinguish us from them." $(B L, 25)$ And it is these same dividing practices at a national stage that delimit and prepare the context for a wholesale denigration of a culture, a history, a people. The process, moreover, follows a schema imbued in affective response, in trauma as embodied in its subjectvessels, individuals and communities bearing the weight of the past in their continued 
living conditions. This is why Anzaldua sees the borderlands as an interzone split between discourses, set without dominant cultures and created "by the emotional residue of an unnatural boundary." (Borderlands, 25) It is indeed the same reason behind why "the prohibited and forbidden are its inhabitants", as the forces that brand them as such are the same as those that begot the interstice of the borderlands as an inhospitable, reductive, and divisive space.

The most significant ramifications of this commingled history and origin for our reading are threefold: firstly, the question of trauma not only culturally and filially inherited, but sourceable to multiple distinct discourses or traditions and constitutive of the border culture Anzaldua theorizes recurrently about; secondly, the condition of a subject thrown into this condition, and its implications not only for a distinct worldedness and practical hermeneutic/meaning-creating activity but for a radically different existential analytic with different priorities and unique perspectives; and thirdly, the sui generis composition of writing, spirituality, resistance, self, affect, ontology, and ethic that, together with the two prior qualities, simultaneously shifts itself into the space left behind by phenomenological description and formulates a new theory that culminates in a praxis of self. To put it another way, Anzaldua spells the end of phenomenology and even puts psychoanalysis into question and on its heels, by taking objectivizing forms as a foundation that undoes itself in the process of creating a more robust mestiza/third-world consciousness better inoculated against the pathologies of oppressive systems. In effect, many of the problematics of traditional metaphysics, psychology, ontology (i.e. Western sciences) are circumvented in the committed writing of a fuller self into being, an 
immune system responsive to repeated trauma received from culture, family, place, history, and structure.

\section{A Life claimed in Wounds: the Pains of a Queer Chicana Poet}

As has been alluded to thus far, the event of the borderland's "genesis" may itself be regarded as traumatic in character, one that is shocking and divisive in impact. The geopolitical circumstances of the American southwest and the cultural memory begotten by what has transpired there over the past 150 years correspond, with a discourse and symbolic system denoting break, assailment, fragmentation, fear, and suppression becoming the norm. Anzaldua characterizes her experience in a totality where the pain sourced from that traumatic assault on the cultural psyche and memory of people ripples down to her, and vice versa; and this continuum of pain is one against which her positionality identifies itself and departs from, the leaving manifesting as an agonized absconding from her origins into herself. Not unlike Freud and Caruth's descriptions of trauma, Anzaldua discovers an identity born from the ashes of personal calamity. And this identity reaches across gaps redolent of the panoply of errata handed down by western philosophy: the mind/body split, the dessication of spirituality, a virtually telepathic and elided sixth sense, and the depths of archetypal unconsciousness.

The place Anzaldua writes about — her natal Aztlan, the American Southwest and Mexican Northeast, as well as the border regions themselves — are the hotbed from which springs her soul and spirit, literally. And Anzaldua goes to great lengths to emphasize this place's pained beginnings: “The U.S. - Mexican border es una herida abierta where the Third World grates against the first and bleeds." (25) Similar yet 
different from the personal and historical wounds we have looked at so far, Chicanx culture has woven into its very fabric a geographical wound, a subculture formed through material lopped off of one part from the whole, a child from its parent culture. The contact scrapes and bruises, hemorrhaging into a pool that nevertheless creates something new. This same moment of departure is traumatic in structure, and defines the cultural identity someone like Anzaldua will write about in her poetry: "1,950 mile-long open wound/dividing a pueblo, a culture,/ running down the length of my body/staking fence rods in my flesh,/splits me splits me/me raja me raja" (Borderlands, 24) Anzaldua is pointing out a factical and embodied circumstance of her time and place: she is a border-being, one of "los atravesados" for whom the claws of domination and hegemony lurk around every corner. And among these, people of Chicanx heritage are of a cultural background and worldedness for which the physical border-wall is a destructive and traumatizing force, the material condition rending the cultural imagination and memory of a people long at the center of a continental divide. Anzaldua's representation of that pain as lesions, cuts, bruises, and wounds on the body stand in for a similarly invasive assault on the body-as-culture and the culture-as-body, an indivisibility of the usual divorcing of the two. Human beings acculturated according to a world they are thrown into, Anzaldua is saying, will feel as flesh torn from flesh when their world is set ablaze. This loss is described by Anzaldua in her brief history of Chicanx culture, where the loss of land by Anglo-American colonization is the same as being "jerked out by the roots, truncated, disemboweled, dispossessed, and separated from our identity and our history." (Borderlands, 30) The material resources and arable land wrenched from her forebears is likened to a corporal extraction, extirpation in the purest and most appalling 
sense. The moment of traumatic break, one Freud defines as crucial to traumatic experience and which Caruth clarifies to be unfathomable to those who have experienced it nevertheless hypostasize as Anzaldua's being-in-the-world, in the preconcious level of cultural meanings infused into her very way of seeing and walking through her world.

As has been shown, then, Anzaldua's language and concepts follow from a condition that appropriately incorporates embodied perception into concept, spirit, and praxis. It follows that Anzaldua is able to visualize a direct connection between place and culture or consciousness, a link at the level of meaning creation she can return to intermittently as part of Nepantla and auto-writing. Indeed, the harm inflicted by Anglo colonization is - she is insistent on this - not only corporal but spiritual, that the damage is done not just to the body, but to the soul. This ensouled quality or mode is something she elsewhere designates as a process resembling meaning-making. She describes, for example, her habit of "look[ing] for omens everywhere, everywhere catch[ing] glimpses of the patterns and cycles of [her] life"10, a practice indicating the direct co-constitution of place and self. What Anzaldua calls spirit we can then, for our purposes, surmise to be roughly translatable to the practice of assigning and receiving meaning to and from the worlds of our practical concern. This practice would be opposed to "objective reality", Heidegger's term for a quasi-mathematical reality which subtends our own worldedness but at the same time is devoid of signification. Anzaldua's criticism of a philosophy unconcerned with cultural and historical meaning and circumstance is rightly directed at European traditions foisted upon non-westerners:

10 (Borderlands, 58) 
They [Western Anthropologists] are fascinated by what they call the 'magical' mind, the 'savage' mind, the participation mystique of the mind that says the world of the imagination - the world of the soul - and of the spirit is just as real as psychical reality. In trying to become 'objective,' Western culture made 'objects' of things and people when it distanced itself from them, thereby losing 'touch' with them. This dichotomy is the root of all violence. $(B L, 59)$

The division of sense from objects, and objects from their senses, is the original sin, the cardinal point of assault where the wedge is driven into the colonial subject by imperial dominators. This break is what allows culture to be lost, and is the primary process the recurrence of which Anzaldua is combatting, on that wants her to "forget that every cell in our bodies, every bone and bird and worm has spirit in it." $(B L, 58)$

This eurocentric determination against alternative realities is ardently criticized by Anzaldua as anti-life, and destructive towards indigeneity, queerness, and femininity, among others. It is the source both of the damage done to her, and yet also the source for her liberatory epistemology. "La facultad" is one segment of the epistemology she constructs in Borderlands/La Frontera, a property integrated into her psyche like a sixth sense which is at the same time utterly contingent and melded to painful and traumatic experiences (including the sudden divorcing from cultural totalities characteristic of European colonial domination in the region). Anzaldua cites the experience of pain, fear, and other affects commonly interpreted as debilitating to the self as a source for the self's defense mechanisms in La facultad, a unique capacity all the more common in those caught between worlds11. Her vision is not limited to the physical, either, as the assault transcends into the spiritual realm as "susto", "a sudden shock or fall that frightens the 
soul out of the body." $(B L, 60)$ So pain runs the gamut from material conditions into consciousness, from the ground up, and Anzaldua continues to detail with remarkable perspicuity a continuum of concepts located at every step of the way. Eventually the entirety of one's being is focused into a defensive scheme, a fortress of solitude:

It is an instant 'sensing,' a quick perception arrived at without conscious reasoning. It is an acute awareness mediated by the part of psyche that does not speak, that communicates in images and symbols which are the faces of feelings, that is behind which feelings reside/hide. The one possessing this sensitivity is excruciatingly alive to the world." $(B L, 60)$

The whole is not deducible from this quick 'sensing', but actionable, a coherent motor organization calibrated towards the prevention of further exterior traumatic stimuli; the system has defined itself by pain, and thus innoculated itself by withdrawals into adamantine shells. The result is a painless, effortless, seamless registry of significant object-beings as they present hazards to the self. And, as much as Anzaldua might emphasize a metaphysical component, la facultad manifests as a "quick perception" displaying a material basis in the body in this particular articulation. The bridging of the mind body split is a spirited being, one vulnerable enough to suggestion or stimulation to demand a shield, no matter the cost. And this impulse to defend has no small pedigree, harkening back to the death drive/pleasure principle dichotomy and duel of fates: it is itself the impulse to repeat, the terrorizing mechanism, which propounds the murky, vile doctrine in order to protract the life of the organism. In this same order, Anzaldua sacrifices one part of herself to enlarge and enbolden the other - a pound of flesh, in return for a piece of heart. Her self-recreation is, in effect, not painless, but pain-bound, a waltz of anguish playing along to the melody of one's autocreation as an autoimmune reaction. Of course, this self is equa-primordial with Heidegger's "They-self”, so the 
resolute breaching into the individuality of one's divergence from the herd defines one's propinquity and tendency to sloughing off the mold as soon as it has cracked under the pressure of limitations and stagnation, a rebirth through the cracks.

Just as importantly is the binary-breaking trope of pain itself, which sets forth destruction and creation from seemingly two separate ends of the spectrum. Pain writes both, a re-integration of the traumatic memory into full self-narrative - one's autohistoria, as Anzaldua may reference. And it is obvious that the recreation, the speakingback-to, the definition by division, by difference, operates on the axis of compulsions. After all, Anzaldua herself mentions this recurrence, albeit in a negative cast: "In order to escape the threat of shame or fear, one takes on a compulsive, repetitious activity as though to busy oneself, to distract oneself $(B L, 67)$ Together, however, with her presence of mind and volitional expansion and envelope-pushing, her discourse periodically expands by just this compulsion towards anguish, self-destruction, a tracking towards that retreating wound. Just as Derrida points to the inability to fully articulate one's being thrown as we are into the differance and trace-logic of language and speech, both temporal and deferred by structure and unconsciousness - Anzaldua embellishes the graceful impossibility, the hopeful unfathomability of the self. It is in its secrets, she reminds us, that our greatest futures await.

\section{The Shadow is our Tyrant, and our Savior: A Reformatting of Ourselves}

Fitting the themes we've so far established of duality and of difference through otherness, Anzaldua's figures and totems of the other in oneself and of the decline preceding the rebirth situate a new set of terms. These are ideas and semiotic systems she 
writes into existence, creates the language for out of the sundry recourses to past experience, memory, and cultural roots. And they are similarly intriguing for their inclusion of otherness as psychically internalized, a development which permits Anzaldua to take action from out of the depths of the lowest lows and into the most exalted highs. Her vocabulary is willfully and enthusiastically hybrid, one that fuses insights from psychoanalysis, western anthropology, meso-american spirituality and myth, feminism, and queer theory. But there is more: an indomitable agency and spirit that refuses theorization drives her committed and passionate involvement. This drive is manifest in Anzaldua's inner turbulence and strife with the symbols of fear, the unconscious, depression and anxiety; they are the Serpent, the Shadow-Beast and the Coatlicue State, respectively.

The Serpent is a figure that looms especially large in Anzaldua's imagination, one she recounts best in a memory of her reprimanding mother, and a corresponding late night — a dark night of the soul? — in which she confronted the external hallucination or condensed symbol of her unconscious drives. It's role in the unconscious is undeniable as, descanting on the Serpent, Anzaldua has this to say: "I realized she was, in my psyche, the mental picture and symbol of the instinctual in its collective impersona, prehuman. She, the symbol of the dark sexual drive, the chthonic (underworld), the feminine, the serpentine movement of sexuality, of creativity, the basis of all energy and life." (Borderlands, 57) Anzaldua's re-interpretation of her ancestral past recovers a beautiful spore of change concealed by a horror, an ancient symbology displaced by a traumatic event — the elimination of matriarchal culture by patriarchal values — and codified as demonic, abhorrent, toxic. It is in her direct confrontation with this speaking 
wound of culture, as Caruth would call it, that Anzaldua solves the puzzle of her own conflict with its values. And she achieves this by a historical literacy and close reading of meso-american and, in particular, Aztec culture, one which denigrated and denounced the honorary feminine in favor of the bloodlust of masculine war-dieties (Borderlands, 4953). In an act of authentic resoluteness (the Heideggerian description of determinations to separate a distinct self from the "they-self"), she distances herself from the more damaging and destructive aspects of her natal traditions while reconstructing and salvaging constituents of her early past.

The Serpent is dually represented as the Shadow Beast. Their features seem to have much in common at first blush, with Anzaldua telling of a grotesque basilisk-like monstrosity that terrorizes her and the women of Chicana or indigenous heritage. The difference lies in each creature's origin: the Serpent is a cultural construct, an archetype foisted upon little girls in Mexican/Chicanx culture. Contrast this with the Shadow-Beast, Anzaldua's creation and representation of her unconscious will as well as her fears, impulses, drives, and other qualities antithetical towards the self. There is a more linear relation implicit in both figures: the Serpent imbues itself into the unconscious from early childhood by way of acculturation, and holds in its grip the child's delicate psyche until all fear itself takes on the form of the Serpent. The twinning effect we want to home in on is Anzaldua's exhortation to consciousness of the dual imposition and demonization of the serpent archetype, a simultaneous vilification of the serpent and its installation as internal policeman in the hearts of young girls especially from an early age. The binary of human and monster and masculine and feminine are matched in patriarchal culture, Anzaldua tells us, and liberating the individualizing and revolutionary potential of the 
feminine also means confronting the beast in the mirror, something "not many jump at... without flinching at her lidless eyes." (Borderlands, 42) It is in fact the learned helplessness, the complicity in one's own imprisonment Anzaldua targets: "Most of us unconsciously believe that if we reveal this unacceptable aspect of the self our mother/culture/race will totally reject us. To avoid rejection, some of us conform to the values of the culture, push the unacceptable parts into the shadows." (Borderlands, 42) This fear of confrontation and suppression of the feminine escapes to the unconscious, the other within oneself. It is here that Anzaldua draws the battle lines and revives the otherness within herself. And what is most important to realize is the nature of this combat: rather than fighting external political struggles exclusively, Anzaldua proposes that we bring the fight home, exorcizing our innermost demons. It is this praxis that resembles a phenomenological twist, an inner gaze and a return to understanding the world as she sees it in her particular hermeneutic subjectivity. It is in reclamation and observance of this world of meaning that resolution lies dormant; and it is in the belly of the beast that the prospect of a newly healed self awaits in.

And so we arrive at the Coatlicue State. To Anzaldua, this further paining and deepening of anguish is paramount to resolution - a darkening night before a new dawn. She repeatedly iterates the dour ambiguity and smirking perplexity in the creature's smile, doubling as it does its meanings in her imagination: fear and hope, desire and despair, blood and love. It can be everything or nothing, and its gaze is everything: "A glance can freeze us in place; it can 'possess' us. It can erect a barrier against the world. But in a glance also lies awareness, knowledge." (64) Anzaldua has already, at this point in the text, discussed gazes and their paralyzing potentiality. And here the idea is 
recycled, pointing towards the same pain-schema which directs epistemological breakthroughs, only in a eerier ambiguity, a non-decision with ramifications for the speaker in their listening. This would be in her remaining faculties, her volition:

The ability to respond is what is meant by responsibility, yet our cultures take away our ability to act - shackle us in the name of protection. Blocked, immobilized, we can't move forward, can't move backwards. That writhing serpent movement, the very movement of life, swifter than lightning, frozen. $(B L, 42-43)$

The serpent can freeze you, while also freeing you; its symbology runs deeply, And most vitally, as a coagulant, a mortar-like mixture binding opposites down to their interstitial gaps. Anzaldua's inner symbology reappears, reflects, deep in the soul's depths, a re-evaluation of the self: "When I was older I would look into the mirror, afraid of mi secreto terrible, the secret sin I tried to conceal - la sena, the mark of the Beast ... ." (64-5) What cannot be stated enough is just how radical Anzaldua's interpretation really is: discovering that her inner demon is in fact her archetype, the Jungian double which stands for the inmost practices and virtues which comprise the most rarefied actualizations of oneself. And for Anzaldua, this figure is profoundly ambivalent, bending in every possible direction at seemingly the same time. Finally, she can accept the function of the Coatlicue state, of the pained spirals of remembrance and wallowing in despair: they are "exactly what propel the soul to do its work: make soul, increase consciousness of itself." Indeed, “Our greatest disappointments and painful experiences — if we can make meaning out of them — can lead us toward becoming more of who we are. Or they can remain meaningless. The Coatlicue state can be a way station or it can be a way of life." (68) A life without pain is no life at all. Not because pain is necessary for us to exist,but that we are most fully ourselves, most fully alive, when we can rebound 
by reconstruction, dispensing with elaborate wounds by reincorporation, by scarring over. A scarring which, it cannot be dismissed, is a return to an intentional and deliberate critical consciousness alive to critique of dominant discourses through perception and by way of a new ontology; a revival of the oppressed and damaged self that in the process recognizes its own imperfectability, and proceeds nonetheless.

\section{Beyond Good and Evil: Refashioning Ourselves as Healing}

Nepantla consciousness is the term Anzaldua arrives at many years after the publication of Borderlands/La Frontera. It is a development of "Mestiza Consciousness", a realm of thinking known for its ambiguities and ambivalences, its disruptive flair as well as its vehemently hybrid expression. The reference to Nietzsche's book in the above subtitle ought to be suggestive of her intentions: to elaborate on her cultural history in addition to her personal one, and in the process break apart the calcified mold of tradition and into herself, a sui generis existence in the world. Anzaldua embraces differences in her self constitution, and therefore survives the most reductive and reducing experiences one can as a human-being: micro-aggression, racism, sexism, homophobia, and outright physical and psychic trauma. And it is in her description of this inter-space conducive to altogether superior memory and self-creating event that we might discover the healing potentialities of such an occurrence. And so deconstructing the language and hybridity of Nepantla will focus our analysis into the concrete moment of survival by deconstruction, a taking on of responsibilities and volition in the face of mass meaninglessness and nihilism; answering the call, in other words, for authentic experience and creation de novo of meaning. 
Never, though, ex nihilo. In her preface to Light in the Dark/Luz en lo Oscuro, "Gestures of the Body", Anzaldua maps out her development of key ideas originally reported on in Borderlands/La Frontera, with essential milestones in her experimental timeline are amplified and refined. Here, the notion of "Nepantla" receives its initial and most succinct treatment, stating how "Nepantla is the place where my cultural and personal codes clash, where I come up against the world's dictates, where these different words coalesce in my writing. . . Nepantala is the point of contact y el lugar between worlds - between imagination and physical existence, between ordinary and nonordinary (spirit) realities." (2) Anzaldua staggers us once more with her metaphorical display: the gap within which, as Derrida reminds us, is the premier scene of writing, and thus creation, is now hers to command. She makes camp in this interstitial space, repeatedly and perpetually renovating her sense of self at the heart of creation itself. And what preserves her participation in this markedly and inveterately difficult-to-inhabit positionality? None other than her writing practice, her direct engagement in remapping the bodily gestures and points of articulation suffered in trauma into the self's code, in its practical sense-making within its everyday world, to the analytic and spiritual ideas repeated routinely and on a daily basis. And this in spite of Derrida's maintenance of a fragmentary, ghostlike identity within which we persist as a trace across time and temporal axes: "The sheer mental, emotional, and spiritual anguish motivates me to 'write out' my/our experiences. More than that, my aspirations towards wholeness maintain my sanity, a matter of life and death." (Light in the Dark (hereby LITD), 2) The desire to reconstitute oneself may as well be inherent, so second-nature is it to Anzaldua's life-force. It calls for breaking new ground in order to shield identity from the 
slings and arrows of outrageous fortune (that is, colonial, racist, and sexist microaggressions deliberate and not) Moreover, the impulse and idealism of completion is foregrounded in spite of its immanent self-defeat. Why? Because it is in enacting that will to completion, to wholeness, that wholeness is not fulfilled but put into practice, therefore endowed with animation as part of a life-as-temporality, an activity sustained by continual renovation of this will and desire to participate in existence.

This continual renovation has a double motivation, outgrowths of a primary valuation of fortifying and extending the self with la facultad: the traumatic origin, tracing further back than the previous few generations and practically into the DNA of those descendants of victims of historical atrocity. It begins with a historical grievance, as well as one for the everyday minutiae: "Each irritant is a grain of sand in the oyster of the imagination. Sometimes what accretes around an irritant or wound may produce a pearl of great insight, a theory." (LITD, 2) Each moment in isolation does not cohere without the overarching sense of la facultad, a reflex imbued with an anxious energy straddling the pleasure principle and death drive. If the wound speaks, it requires a listener, a witness to the damage who will appraise its pain and pass judgment on its perpetrator. The concatenations she puts together amount to a syntactical unit, furnishing sense to what was once only disordered stimuli unevenly arranged and outside all rational legibility. And this sense-giving act will form a coherent whole in the arena of Anzaldua's epistemological modes, among them Nepantla.

To a certain degree, Nepantla modes are ends in themselves: they allow one to access tensions, a differential consciousnesses of phenomena common to experience unearthed in a new light. To another eye, Nepantla is a means to an end, one in which 
Anzaldua believes she is better able to write, and in turn "idear", a procedure where she becomes comfortable "develop[ing] an epistemology of the imagination, a psychology of the image" where she can "construct [her] own symbolic system." $($ LITD, 2) To Anzaldua, the act of writing stems from a Nepantla consciousness, and enables her to engage with reality in a creatively self-affirming mode, one where she bears witness to her production of self. The activity of writing, resembling the same psychoanalytic premises surmised in our earlier readings of Freud and Caruth, becomes one in which Anzaldua ceaselessly retrospects for the sake of reforming the future, a hermeneutic of liberation - and one embedded in the recovery of one's own narrative memory into a cogent one, resolved from the traumatic exclusions jeopardizing its temporal integrity. The image this process engenders can appear paradoxical and aporetic:

Intento dar testimonio de mi propio proceso y conciencia de escritora chicana. Soy la que escribe y se escribe/I am the one who writes and who is being written. Últimamente es el escribir que me escribe/ It is the writing that 'writes' me. I 'read' and 'speak' myself into being. (LITD, 3)

She processes and works through by — against everything Felman, Laub, and Caruth would suppose - bearing witness to herself. She is herself the site of being changed and doing the changing, having her cake and eating it too. But in fact, Anzaldua's move is lateral, accessing the inherited and available discourses of collective myth and memory. This is an understandable response, given that the act of testimony has been ripped from her arsenal subjectivity by colonizing discourses: Anzaldua is faced with the internal looping traps of traumatic experience. Her saving grace is the defenses of the collective, shared cultural memory, the inheritance and reapplication of which is already a deeply 
critical act. More yet in the act of writing, where, as Anzaldua describes it, a historically bound subjectivity and worldedness is being painfully reinscribed

And the passage's bilinguality only reinforces this reading, demonstrating two of her several conflicted identities and dichotomy of the meanings produced in Spanish, in English, and from both juxtaposed together. A seemingly liquid spirit connects the two expressions in act symbolizing collective and coalitional action. Her representation of multiple identities is proof positive for allied political actions. Not coincidentally, then, Anzaldua is much more concerned with writing as a spiritual act in Light in the Dark/Luz en lo Oscuro than she was in Borderlands/La Frontera, the corresponding salient feature of the latter consisting in spirituality and religion. Where the older book copes with the mythologies of others handed down to her, the newer one affords a mundane task with spiritual properties equal to the task of inspiring the creation of an entirely new self. This time, furthermore, in a much more materially grounded form more disposed to political action. It is the body itself on which writing is performed, directed, and thus the recognition of the language and discourse a material entity carries is brought to the center. Anzaldua confirms this, remarking on how "writing is a gesture of the body, a gesture of creativity, a working from the inside out ... the body is the ground of thought. The body is a text." $($ LITD, 5) Recovering the factical circumstances of oneself as an embodied being allow one to rediscover the wounded body, the self as carnal, etched in blood with claws sharp enough to dig deep. Until this reality is unearthed, then the signs of traumatic experience will speak with disembodied voices, and a response - in writing conscious of itself and its limited corporeal state - along the same venues where the damage was done, individually and collectively, in the first place. And so Anzaldua's 
politics, already so imbued with spirit and co-extensive with activism, finds another outlet in writing, and therefore directly imprints itself onto the body and the material world. As far as her epistemology is concerned, it is more an ontology; and as far as her ontology is concerned, it is more a theory of contingent subjectivity. And is that not just the same as literature, as poetry?

The culmination of this work are the dynamic tandem of "autohistoria" and "autohistoria-teoria", translatable roughly to auto-history and autohistory-theory. They are modes or moods Anzaldua uncovers as part of what she identifies as the continual death and rebirth cycle of the oppressed self, a cycle she deliberately codifies into her writing. The writing she produces is this autohistoria, itself a codification, an archiving of oneself as testimonial, as record.

A similar course was run by European Continental philosophy in the 20 th century, one diverging from metaphysics to existence philosophy and politics. What distinguishes autohistoria is a critical, or what we could even refer to as deconstructive, attitude which denies a pure authority to tradition and calcified common discourse. This resembles the rejection of the natural attitude characteristic of Husserlian phenomenology, an idea invested in a return to actual and essential features of consciousness. After passing through Heidegger, Merleau-Ponty, and Derrida, however, the same axiom undergoes revolutionary revision: "consciousness" becomes existence, the body, and the text; the "natural attitude" becomes a critique of historical constructs and discourses; and “essence" becomes contingency, history, and subjectivity. Where then does that leave us, when confronted with a perspective like Anzaldua's? A critical, nonconformist, heterodox, fluid identity takes shape: the conclusions given by this strand of Continental 
thought come full circle, returning to the root of phenomenological thought - the subject's experience of their world - and rejuvenates it by embodying what European philosophers have only just begun to catch onto. Anzaldua's lived experience represents a fuller potential for authentic living by not only undoing binaristic thinking in a theoretical or textual vein, but expanding the text to the living body and swirling spirit, in addition to making it a conscientous personal habit or practice. The corrolary of phenomenology is to disclose the self, $a$ self, an individual thrown into a set of circumstances not of their own choosing, into a material and corporeal existence, one fraught by the wounds of racial conflict, gender oppression, colonial persecution, and hetero-hegemony. It becomes the imperative of that individual not to philosophize in grandiloquent tones about firmaments, but to entrench themselves into their ownmost possibilities and projects, the meanings culturally native to them, and the search for their own and other's freedoms.

But the practice does not end there, not with the individual. Autohistoria has a basic communicative function, a social dimension written into its DNA. The foundation of philosophy, according to thinkers like Hegel, Freud, or Nietzsche, is in describing concrete realities and drawing conclusions from the grounds of this experience in the world; pure reason and divine providence, in other words, ought to have no say. Anzaldua parlays this assumption into one not only concerned with personal, individual experiences, but the ways in which these individual's experiences are sewn into larger, collective struggles. She confirms the direct line from rewriting oneself to political events when she states how "Conectando experiencias personales con realidades sociales results in autohistoria, and theorizing about this activity results in autohistoria-teoria. It's a way of inventing and making knowledge, meaning, and identity through self-inscriptions.” 
$(L I T D, 6)$ Anzaldua actively rejects any divisions from what we might consider distinct areas of life (politics, the personal, the spiritual) in order to facilitate social engagement, and autohistoria is her weapon of choice. All of this for the sake of "attempt[ing] to show (and not just tell) how transformation happens." $($ LITD , 7)

\section{Conclusion: Nepantlera, Once More}

The concept of nepantla, the liminal threshold within which fragmentating selves float, in between decision, direction, and transformation, makeup the core of Anzaldua's process. The thread of nepantla reaches as far back as the inciting incident, the moment of wounding. Referring to them as "arrebatos", quaking raptures nearly throwing the soul out of the body, Anzaldua relates unequivocally how these moments of shock transform previous states into nepantla, a roadway between pasts and futures. $($ LITD, 17) Not dissimilarly, phenomenology relies on breakages - whether a thuderclap, a strike of inspiration, or a dispassionate withdrawal - that reveal features of the world previously undisclosed to us; alternatively, in psychoanalysis, the represssive mechanisms of the unconscious bar external threats (an analyst, or a sleuthy friend) from accessing repressed material by invoking strong affective denials: only in eliciting unconscious material by free-association, automatic writing, and talk therapy are creative connections are drawn and meaning is created, putting an end to the neurosis. What Anzaldua appears to be attempting is a synthetic amalgamation of the two: she retains the striking moments of breakage, yet also reveres a fluent source of words, texts, ideas, meaning; a bridging which paves the way for a reconstruction post-deconstruction, a program packaging together the self, critique, change, and activism under a single guiding light. 
Until then, Anzaldua commits herself to instances of nepantla as chances for growth, for creation. The founding split repeats, the birth of the borderlands reappears as compulsion, and the cracks turn to hard pavement. But in looking that death in the face, Anzaldua unearths new life. As she redefined Coatlicue as a savior goddess, avows her ambiguity as the goddess of both life and death, the compulsion to re-enact the traumas of colonization of the land and its people forces her to ravage herself in the same kind of splitting. Only this time, Anzaldua will turn it to her advantage. Trauma may be perpetually repeatable, but nothing repeats perfectly: iterability will dictate a difference, every time. So if she is condemned to that past, to a tragic revision of its origins, then so be it - but she will force it, bend it to her will, to fashion a being that commands its wounds, not the other way around. Imposing her will, she rescues herself from extinction - and her doing it within the liminal space of nepantla is what will earn her the title of nepantlera, a shamanisitic creator who embraces agony and struggle in order to surpass her wounded selves and commit to a conscious activism.

Work like Anzaldua's will therefore never be concerned with impeccable logical consistency or theoretical coherency, and therefore should not be read as such: she is after all not after conceptual rigor, but self-awakening. At the same time, the peculiarly literary qualities of her work do not prevail either, with sheer poetry being punctuated by assertion, exhortation, demands, critique, and so on. Anzaldua, true to her form, enacts a structure dispelling the old myths of philosophy and poetry, a dichotomy sealed by histories both Western and otherwise; and in its place, resolves a form of writing concealed underneath the binary (a phenomenological move), one constitutive of selftowards-the-future while at the same time resolutely attesting to the past. Anzaldua's 
writing, in other words, is one that builds her sense of identity in the process of its creation, a reclamation and an oppositional criticism that discovers as it regenerates, incorporating each finding into the body as a tattoo etched on bare skin. We may refer to this act by many names: Chicana existentialism, Feminist phenomenology, Queer trauma theory, Mestiza deconstruction. Anzaldua would accept all these and more, as she writes on in a repetition of dismemberment and re-memberment, rebuilding what has been struck down by dominant kyriarchical structures, and enlarging her power and presence for the personal-in-politics, and towards a communal soul. 


\section{Bibliography}

Anzaldúa Gloria. Light in the Dark/Luz En Lo Oscuro: Rewriting Identity, Spirituality, Reality . Edited by AnaLouise Keating, Duke University Press, 2015. Print.

Anzaldúa, Gloria. Borderlands/La Frontera: The New Mestiza. 4th ed., Aunt Lute Books, 2012. Print.

Bond, Lucy, and Stef Craps. Trauma. Routledge, 2019. Print.

Caruth, Cathy, editor. Trauma: Explorations in Memory. Johns Hopkins Univ. Press, 1995. Print.

Caruth, Cathy. Unclaimed Experience: Trauma, Narrative, and History. Johns Hopkins University Press, 2016. Print.

Derrida, Jacques. Speech and Phenomena: and Other Essays on Husserls Theory of Signs. Translated by David B. Allison, Northwestern University Press, 1973. Print.

Derrida, Jacques. Margins of a Philosophy. Translated by Alan Bass, Univ. of Chicago Press, 1997. Print.

Felman, Shoshana, and Dori Laub. Testimony Crises of Witnessing in Literature, Psychoanalysis and History. Taylor and Francis, 2013. Print.

Freud, Sigmund. Beyond the Pleasure Principle. Translated by James Strachey, Norton, 1989. Print.

Hall, Stuart. "Cultural Identity and Diaspora." Identity: Community, Culture, Difference. Ed. Jonathan Rutherford. Lawrence \& Wishart, 1998. 222-237. Print.

Heidegger, Martin. Being and Time. Translated by Joan Stambaugh, State University of New York Press, 2010. 